DiRECTEUR DE LA PUBLICATION: Bruno David,

Président du Muséum national d'Histoire naturelle

RÉdACTEUR EN CHEF / EDITOR-IN-CHIEF: Didier Merle

ASSISTANTS DE RÉDACTION / AsSISTANT EDITORS: Emmanuel Côtez (geodiv@mnhn.fr); Anne Mabille

MISE EN PAGE / PAGE LAYOUT: Emmanuel Côtez

COMITÉ SCIENTIFIQUE / SCIENTIFIC BOARD:

Christine Argot (MNHN, Paris)

Beatrix Azanza (Museo Nacional de Ciencias Naturales, Madrid)

Raymond L. Bernor (Howard University, Washington DC)

Alain Blieck (USTL, Villeneuve d'Ascq)

Henning Blom (Uppsala University)

Jean Broutin (UPMC, Paris)

Gaël Clément (MNHN, Paris)

Ted Daeschler (Academy of Natural Sciences, Philadelphie)

Bruno David (MNHN, Paris)

Gregory D. Edgecombe (The Natural History Museum, Londres)

Ursula Göhlich (Natural History Museum Vienna)

Jin Meng (American Museum of Natural History, New York)

Brigitte Meyer-Berthaud (CIRAD, Montpellier)

Zhu Min (Chinese Academy of Sciences, Pékin)

Isabelle Rouget (UPMC, Paris)

Sevket Sen (MNHN, Paris)

Stanislav Štamberg (Museum of Eastern Bohemia, Hradec Králové)

Paul Taylor (The Natural History Museum, Londres)

COUVERTURE / COVER:

Réalisée à partir de la Figure 1 de cet article/created from Figure 1 of this article

Geodiversitas est indexé dans / Geodiversitas is indexed in:

- Science Citation Index Expanded (SciSearch ${ }^{\circledR}$ )

- ISI Alerting Services ${ }^{\circledR}$

- Current Contents ${ }^{\circledR}$ / Physical, Chemical, and Earth Sciences ${ }^{\circledR}$

- Scopus ${ }^{\circledR}$

Geodiversitas est distribué en version électronique par / Geodiversitas is distributed electronically by:

- BioOne ${ }^{\circledR}$ (http://www.bioone.org)

Les articles ainsi que les nouveautés nomenclaturales publiés dans Geodiversitas sont référencés par / Articles and nomenclatural novelties published in Geodiversitas are referenced by:

- ZooBank ${ }^{\circledR}$ (http://zoobank.org)

Geodiversitas est une revue en flux continu publiée par les Publications scientifiques du Muséum, Paris Geodiversitas is a fast track journal published by the Museum Science Press, Paris

Les Publications scientifiques du Muséum publient aussi / The Museum Science Press also publish: Adansonia, Zoosystema, Anthropozoologica, European Journal of Taxonomy, Naturae.

Diffusion - Publications scientifiques Muséum national d'Histoire naturelle

CP $41-57$ rue Cuvier F-75231 Paris cedex 05 (France)

Tél. : 33 (0)1 40794805 / Fax: 33 (0)1 40793840

diff.pub@mnhn.fr / http://sciencepress.mnhn.fr

(C) Publications scientifiques du Muséum national d'Histoire naturelle, Paris, 2018

ISSN (imprimé / print): 1280-9659/ ISSN (électronique / electronic): 1638-9395 


\title{
New sabre toothed Felidae (Carnivora, Mammalia) in the hominid-bearing sites of Toros Menalla (late Miocene, Chad)
}

\author{
Louis de BONIS \\ Université de Poitiers, IPHEP (UMR 7262 CNRS) UFR SFA, Bât. B35, TSA 51106, \\ F-86073 Poitiers cedex 9 (France) \\ louis.de.bonis@univ-poitiers.fr \\ Stéphane PEIGNÉt \\ CR2P UMR 7207 (CNRS, MNHN, UPMC, Sorbonne Université), \\ Muséum national d'Histoire naturelle, Département Origines et Évolution, \\ case postale 38, 57 rue Cuvier, F-75231 Paris cedex 05 (France) \\ Hassane Taisso MACKAYE \\ Andossa LIKIUS \\ Département de paléontologie, Université de N'Djamena (Tchad) \\ Patrick VIGNAUD \\ Michel BRUNET \\ Université de Poitiers, IPHEP (UMR 7262 CNRS) UFR SFA, Bât. B35, TSA 51106, \\ F-86073 Poitiers cedex 9 (France)
}

Submitted on 18 May 2017; accepted on 2 October 2017; Published on 15 February 2018

KEY WORDS

Tchad,

Miocene,

Carnivora,

Felidae,

Machairodontinae, new record, new genus, new species.
urn:Isid:zoobank.org:pub:2E49A6A0-6E02-4A71-870B-5D3BA18E8E81

Bonis L. de, Peigné† S., Mackaye H. T., Likius A., Vignaud P. \& Brunet M. 2018. - New sabre toothed Felidae (Carnivora, Mammalia) in the hominid-bearing sites of Toros Menalla (late Miocene, Chad). Geodiversitas 40 (3): 69-86. https://doi.org/10.5252/geodiversitas2018v40a3. http://geodiversitas.com/40/3

\section{ABSTRACT}

The late Miocene fossil-bearing localities of Toros Menalla (Chad) have yielded a huge amount of vertebrate remains with, in particular, the hominid Sahelanthropus tchadensis Brunet et al., 2002. The order Carnivora is well represented in the fauna (with up to 23 species) and we describe here a new genus and species together with a species not previously recorded in the fauna. Both species belong to the saber-toothed felids. The new genus, size of a lynx, is known by jaws and several post-cranial bones. It displays in the upper canines, mandible and bones of the fore limb some features indicating machairodont affinities. The second genus, size of a leopard and well known in Africa, is only present through a characteristic upper canine. The presence of eight species of Felidae into 23 species of carnivorans is much rare into the Miocene carnivoran assemblages and is discussed in the conclusions. 


\begin{abstract}
RÉSUMÉ
Nouveaux Felidae à dents de sabre (Carnivora, Mammalia) des sites à hominidés de Toros Menalla (Miocène supérieur, Tchad).

Les localités fossiliferes du Miocène supérieur de Toros Menalla (Tchad) ont livré une énorme quantité de fossiles, parmi lesquels se trouve l'hominidé Sahelanthropus tchadensis Brunet et al., 2002. L'ordre des Carnivora est bien représenté dans cette faune avec 23 espèces reconnues à ce jour. Nous décrivons ici un genre nouveau et une espèce nouvelle ainsi qu’une autre espèce qui n’avait jamais jusqu’ici été signalée à Toros Menalla. Ces deux félins se rattachent aux félidés à canines supérieures en lame de sabre. Le nouveau genre (de la taille d'un lynx) est connu par des mâchoires et une bonne partie du squelette post-crânien. Il présente sur les canines supérieures, la mandibule et plusieurs éléments du squelette appendiculaire plusieurs traits qui le rapprochent des félidés machairodontes. Le deuxième genre, déjà bien connu en Afrique, atteint la taille d'un léopard. Il n'est représenté que par une canine supérieure mais celle-ci, caractéristique, permet une détermination au niveau du genre. La présence de huit espèces de félidés dans une liste de 23 carnivores est extrêmement rare dans un assemblage de carnivores miocènes et sera discutée en conclusion.

MOTS CLÉS

Tchad,

Miocene,

Felidae,

Machairodontinae signalement nouveau,

genre nouveau, espèce nouvelle.
\end{abstract}

\section{INTRODUCTION}

The order Carnivora Bowdich, 1821 plays an important role in the mammalian faunas and its presence may modify the spectrum of the whole fauna (Legendre 1986). Carnivorans are present in several African Miocene faunas but those of the late Miocene are rare and they often contain few carnivoran taxa (Werdelin \& Peigné 2010) except in North Africa with the sites of Sahabi (Howell 1987) geologically situated at the Miocene-Pliocene limit (6-4.8 Ma), and in East Africa with the upper part of the Nawata Formation at Lothagam, Kenya (Werdelin 2003) dated to 6.54 to $c .5 .5$ Ma, Lemudong'O, Kenya (Howell \& García 2007) dated around $6 \mathrm{Ma}$, the Lukeino Fm (Morales et al. 2005) dated to 6.1 to $5.7 \mathrm{Ma}$ and the Middle-Awash, Ethiopia (Haile Selassie et al. 2004) dated around 6-5.5 Ma. Close to the limit of the Miocene are the Pliocene sites of Langebaanweg (Hendey 1974, 1978, 1980; Werdelin et al. 1994) with also a rich fauna of Carnivora. There was a blank in the maps in central African territories. This blank is now filled by the fossils from the sites of Toros Menalla in the Djourab desert, Chad. These sites have yielded the hominid Sahelanthropus tchadensis Brunet et al., 2002 together with a rich vertebrate fauna (Vignaud et al. 2002). Radiochronological ages were proposed for the hominid localities of TM between 7.2 Ma and 6.8 Ma (Lebatard et al. 2008) and between 7.5 and 7.1 $\mathrm{Ma}$ (Lebatard et al. 2010). The fauna includes several carnivoran taxa: Mustelidae (Peigné et al. 2008a; Bonis et al. 2009), Canidae (Bonis et al. 2007a), Herpestidae (Peigné et al. 2005b, 2008b), Viverridae (Peigné et al. 2008b), Hyaenidae (Bonis et al. 2005, 2007b, 2010a) and Felidae (Peigné et al. 2005a, 2008b; Bonis et al. 2010b). The family Felidae shares with Nimravidae and Barbourofelidae the higher degree of specialization for killing and meat slicing among the Carnivora with trenchant P3-P4 and p4-m1 associated to powerful jaw muscles and to a long upper canine. Six taxa of Felidae had been previously described from Toros Menalla (Peigné et al. 2005a, 2008b; Bonis et al. 2010b) but the new material presented in this article, comprising a medium-sized and a larger felids, increases significantly the list of the latter family in these sites.

\section{MATERIAL AND METHODS}

The comparative sample of extant carnivorans comes from the collections of the University of Poitiers (Panthera leo (Linnaeus, 1758), Lynx lynx (Linnaeus, 1758), Caracal caracal (Schreber, 1776), Felis catus Linnaeus, 1758) and, especially for the postcranium, from the zoology and mammalogy collections of the Muséum national d'Histoire naturelle de Paris (Panthera pardus (Linnaeus, 1758), Neofelis nebulosa (Griffith, 1821), Lynx lynx (Linnaeus, 1758), Leptailurus serval (Schreber, 1776), Puma concolor (Linnaeus, 1771), Leopardus pardalis (Linnaeus, 1758), Prionailurus viverrinus (Bennett, 1833), Prionailurus bengalensis (Kerr, 1792), and Pardofelis temminckii (Vigors \& Horsfield, 1827)). For the nomenclature of extant species we followed MacDonald (2001).

Our comparative fossil sample includes a large number of Miocene taxa of Machairodontinae, based on study of casts or original specimens and from the litterature.

Dental nomenclature follow Smith \& Dodson (2003), except the use of buccal instead of labial. See Peigné \& Heizmann (2003) for precise definitions of measurements.

Measurements are in $\mathrm{mm}$ and were taken with verniercalipers to the nearest $0.1 \mathrm{~mm}$.

\begin{tabular}{|c|c|}
\hline \\
\hline \multicolumn{2}{|c|}{$\begin{array}{l}\text { ABBREVIATIONS } \\
\text { aac } \quad \text { anterior accessory cus }\end{array}$} \\
\hline aacd & anterior accessory cuspid; \\
\hline pac & posterior accessory cusp; \\
\hline pacd & posterior accessory cuspid; \\
\hline $\mathrm{L}$ & maximum length; \\
\hline W & maximum width; \\
\hline Lskull & $\begin{array}{l}\text { length of skull, between anterior border of premaxilla } \\
\text { and anterior border of foramen magnum; }\end{array}$ \\
\hline Diast & diastema; \\
\hline DMp2-3 & $\begin{array}{l}\text { lingual depth of the dentary between } \mathrm{p} 2 \text { and } \mathrm{p} 3 \text { (or } \\
\text { between any other teeth); }\end{array}$ \\
\hline $\mathrm{TMp} 3 / \mathrm{m} 1$ & thickness of the dentary across $\mathrm{p} 3 / \mathrm{m} 1$; \\
\hline HPrm1 & height of the protoconid of $\mathrm{m} 1$; \\
\hline TBucm 1 & trigonid buccal length of $\mathrm{m} 1$; \\
\hline LlingP4 & lingual length of the $\mathrm{P} 4$; \\
\hline $\mathrm{LMeP} 4$ & length of the metastyle of $\mathrm{P} 4$; \\
\hline LPaP4 & length of the paracone of $\mathrm{P} 4$; \\
\hline $\mathrm{HPaP} 4$ & height of the paracone of $\mathrm{P} 4$; \\
\hline $\mathrm{Ph}$ & phalanx/phalanges; \\
\hline
\end{tabular}




$\begin{array}{ll}\text { Prox } & \text { proximal; } \\ \text { Mc } & \text { metacarpal; } \\ \text { Mt } & \text { metatarsal; } \\ \text { ML } & \text { mediolateral. }\end{array}$

\section{Institutional abbreviations}

FYROM Former Yugoslavian Republic of Macedonia; GSI Geological Survey of India, Calcutta;

MNHN-ZM-MO and MNHN-ZM Collections of zoology and mammalogy, Muséum national d'Histoire naturelle, Paris;

SAM PQ-L Collections from Langebaanweg, South African Museum-Iziko, Cape Town;

TM Fossils from Toros Menalla, Centre national d'Appui à la Recherche (CNAR, Service des collections), N'Djamena (during the study, temporarily in University of Poitiers, UMR 7262 iPHEP).

\section{SYSTEMATIC PALAEONTOLOGY}

Order CARNIVORA Bowdich, 1821

Suborder FELIFORMIA Kretzoi, 1945

Family FELIDAE Fischer, 1817

Subfamily MaChairodontinaE Gill, 1872

\section{Tchadailurus n. gen.}

TyPE AND ONLY SPECIES. - Tchadailurus adei n. sp.

ETyMology. - Derived from the name of the country and -ailurus, meaning cat in Greek.

Diagnosis. - Same as the type and only species of the genus.

\author{
Tchadailurus adei $\mathrm{n} . \mathrm{sp}$.
}

(Figs 1-5; Tables 1-7)

HOLOTYPE AND SINGLE SPECIMEN. - TM 112-00-99: elements of a skull and partial skeleton including a left isolated I3, a left maxilla with canine, P3-M1 and a part of the zygomatic arch; right I2-I3 in a piece of premaxilla, a fragment of right maxilla with $\mathrm{P} 3-\mathrm{P} 4$, and an isolated left M1. A piece of left hemi-mandible with $\mathrm{p} 3-\mathrm{m} 1$, a fragment of the top of the left coronoid process, a left lower canine whose crown is partly broken off; a right hemi-mandible with c-m 1 , and quite complete ascending ramus. There are also one piece of periotic bone and small fragments of skull including a fragment of basioccipital and the right occipital condyle. This material is somewhat fragmentary but very well preserved without any distortion and it belongs certainly to a single individual. Postcranial remains comprise: proximal fragment of left scapula; distal two-thirds of left humerus and distal fragment of right humerus; subcomplete left radius and epiphyses of right and left radius; subcomplete right ulna and fragment of diaphysis of left ulna; left scapholunar; left hamatum; right trapezium; right and left pisiforms; left Mc I to V, right Mc I, fragmentary Mc II, IV and V, Ph I; fragmentary left and right pelvis; diaphysis of right femur, distal fragment of diaphysis and distal epiphysis of left femur, left and right greater trochanters; left and right patellae; fragmentary proximal epiphysis of left and right tibias, distal fragment of diaphysis and distal epiphysis of right tibia and distal epiphysis of left tibia; fragmentary distal epiphysis of right fibula; right and left calcanei; right astragalus; subcomplete left and right cuboids; left lateral cuneiform; left intermediate cuneiform; right $\mathrm{Mt}$ II and Mt III, left Mt II (subcomplete), Mt IV and Mt
$\mathrm{V}$ (subcomplete); left and right proximal phalanx of the first digit, 9 additional proximal phalanges, 6 middle phalanges of the manus, 5 middle phalanges of the pes, 7 distal phalanges; fragments of ribs; subcomplete atlas; subcomplete cervical vertebra; fragment of lumbar vertebrae; and numerous fragments of undetermined cervical/thoracic/lumbar vertebrae; 10 more or less complete caudal vertebrae.

ETYMology. - Derived from "adei", meaning small in Goran (local language) and stressing the size difference between this species and the other machairodonts from Toros Menalla.

Type AND Only LOCALITY. - TM 112, Toros Menalla, Chad.

Geological AGE. - Late Miocene c. 7 Ma.

DiAgNosis. - Dental formula: 3/3? I, 1/1 C, 2/2 P, 1/1 M. Felidae characterized by a tall, flattened upper canine with mesial and distal keels, the latter with striations; absence of $\mathrm{P} 2 / \mathrm{p} 2$; reduced $\mathrm{p} 3$; P4 with small pre-parastyle (ectostyle) and relatively long metastyle; mandible with reduced symphyseal angle and lowly situated mandibular condyle; extremely short and wide Mc I, with an articular surface for the trapezium that extends along half of the Mc I length; Mc I associated to a particularly robust proximal phalanx that reach up to $90 \%$ of the Mc I length.

DifFERENTIAL DIAGNOSIS. - Differs from all the extant felids by the double keeled upper canine with striations in the distal keel; the relatively low dentary symphyseal angle (except for Neofelis); the low position of the mandibular condyle; the short and wide Mc I; and by a first phalanx of digit I more robust (except in Prionailurus viverrinus and Leopardus pardalis) and much longer relative to the Mc I length. Differs from Dinofelis Zdansky, 1924 species in its smaller size, a less robust upper canine and the absence of $\mathrm{p} 2$. Differs from the Eumachairodontia (sensu Christiansen 2013) in the absence of scimitar or large dirk upper canine and the more developed protocone of $\mathrm{P} 4$.

\section{DESCRIPTION}

\section{Maxilla (Fig. 1A)}

Visible in the left part, the lateral side of the maxilla is almost flat with two small depressions above $\mathrm{P} 3$ and $\mathrm{P} 4$ respectively. The infraorbital foramen is situated $14 \mathrm{~mm}$ above P3 but, the higher part being broken off, we cannot indicate its precise size. The lower rim of the orbit is $24 \mathrm{~mm}$ above P4. The zygomatic arch is high, relatively to the size of the maxilla, and the suture between maxilla and jugal bones is totally fused although, based on tooth wear, the specimen belongs to a young adult. The diastema between the canine and P3 is $9.3 \mathrm{~mm}$ long.

\section{Upper dentition (Fig. 1A; Table 1)}

The $\mathrm{I} 1$ is not preserved. The I2 is very small (height = $4.3 \mathrm{~mm}$ ); the buccal face is simple slightly convex, ogival shaped with a rounded top and a widened lower part. The buccal face is triangular with a basal large cusp separated from the main cusp by a valley. The root (length = about $9.5 \mathrm{~mm}$ ) is mesio-distally compressed. The I3 has a long $(14.8 \mathrm{~mm})$ and curved root. The crown is far larger than that of $\mathrm{I} 2$ and reaches 8.5 in length and $8.6 \mathrm{~mm}$ in height; in buccal view, it is asymmetrical, the distal half being larger than the medial one; there are two sharp crests, mesially and distally. In the lingual face, there is, , a mesially located small cusplet at mid-height; there is no lingual cingulum or talon. The crown of the canine (Fig. 1A1-A3) is elongated, 
TABLE 1. - Measurements in mm of the dentition of Tchadailurus adei n. gen., n. sp. (TM 112-00-99). Symbol: *, estimates. Abbreviation: postc, postcanine. See Material and methods for additional abbreviations.

\begin{tabular}{|c|c|c|c|c|c|c|c|c|c|c|c|c|c|c|c|c|c|c|c|c|c|}
\hline \multicolumn{3}{|c|}{12} & \multicolumn{3}{|c|}{13} & \multicolumn{2}{|c|}{ C } & \multicolumn{3}{|c|}{ P3 } & \multicolumn{6}{|c|}{ P4 } & \multicolumn{2}{|c|}{ M1 } & \multirow{2}{*}{$\begin{array}{l}\text { Diast } \\
\text { C-P3 }\end{array}$} & \multirow{2}{*}{$\begin{array}{c}\text { LP3- } \\
\text { M1 }\end{array}$} & \multirow[b]{2}{*}{ LC-M1 } \\
\hline $\mathbf{L}$ & w & Hbuccal & $\mathbf{L}$ & $\mathbf{w}$ & Hbuccal & $\mathbf{L}$ & $w$ & $\mathbf{L}$ & $\mathbf{w}$ & $\mathbf{H}$ & $\mathbf{L}$ & LlingP4 & w & HPaP4 & LPaP4 & LMeP4 & $\mathbf{L}$ & $\mathbf{w}$ & & & \\
\hline 2.6 & 3.2 & 4.6 & 4.4 & 4.7 & 8 & 11.7 & 7.7 & 13.1 & 6.4 & 7.7 & 21.6 & 21.3 & 11.5 & 11 & 8.6 & 8.9 & 5 & 11 & 5.8 & 36 & 55.5 \\
\hline
\end{tabular}

\begin{tabular}{|c|c|c|c|c|c|c|c|c|c|c|c|c|c|c|c|}
\hline \multicolumn{3}{|c|}{ c } & \multicolumn{3}{|c|}{ p3 } & \multicolumn{3}{|c|}{ p4 } & \multicolumn{4}{|c|}{$\mathrm{m} 1$} & \multirow{2}{*}{$\begin{array}{c}\text { Lp3- } \\
\text { m1 }\end{array}$} & \multirow{2}{*}{$\begin{array}{l}\text { Lpostc- } \\
\text { m1 }\end{array}$} & \multirow{2}{*}{$\begin{array}{c}\text { Diast c- } \\
\text { p3 }\end{array}$} \\
\hline $\mathbf{L}$ & $\mathbf{w}$ & Hbuccal & $\mathbf{L}$ & w & $\mathbf{H}$ & $\mathbf{L}$ & w & $\mathbf{H}$ & $\mathbf{L}$ & w & TBucm1 & HPrm1 & & & \\
\hline 9 & 6.2 & 18.2 & $9.8^{*}$ & $5.1^{*}$ & 6.6 & 14 & 6.6 & 9.3 & 15.3 & 7.3 & 14 & 8.8 & 39.5 & 52.5 & 13.5 \\
\hline
\end{tabular}

\begin{tabular}{cccccc}
\hline TMp3 & TMm1 & DMp2-3 & DMp3-4 & DMp4-m1 & DMm1dist \\
\hline 9 & 10.4 & 18.5 & 17.4 & 20 & 21 \\
\hline
\end{tabular}

relatively thin, with a convex buccal face and a slightly convex, flattened lingual face; there is a smooth mesial edge, followed lingually by a deep groove all along the crown in which fossilization induced a fissure. Distally there is a sharp finely striated edge (Fig. 1D). The indices have been compared with those of extant Lynx Kerr, 1792 and Caracal Gray, 1843. The breadth-length index $(\mathrm{b} / \mathrm{L} \times 100)$ measured at the neck is 72 , smaller than those of the species of Lynx and Caracal as well, although closer to the latter. Nonetheless the neck area between crown and root is more rounded than the quite flattened crown. The $\mathrm{P} 1$ and $\mathrm{P} 2$ are absent. The $\mathrm{P} 3$ (Fig. 1A1-A3) has a robustness index (b/L) similar to that calculated in Lynx and Caracal. Nevertheless the shape is different from those of the extant genera. It is high and the lateral outline is about triangular but the mesial part has a slightly sigmoid outline and ends by a flexion, contrary to Lynx and more similar to Caracal. The distal edge is thin with a pac. Contrary to both extant genera, the maximum breadth is distally situated and the mesial half of the crown is thinner. A discrete cingulum surrounds the basis of the crown and distally gives a small turning up talon. The length of P3 relatively to P4 is similar to that of Caracal and smaller than that of Lynx. P4 seems thicker than in the comparative samples but it is due to the development of the lingually extended protocone whereas paracone and metastyle are thin; the protocone is located more posteriorly than the parastyle. The latter is very well developed. The high paracone is convex in the buccal surface and flat in the lingual one except a strong vertical pillar beginning close to the top and finishing just behind the protocone. The metastyle is more elongate than those of extant felids. A large wear facet extends from the distal part of the pillar to the distal end of the crown. M1 is a short but bucco-lingually extended triangle. It is possible to distinguish buccally a parastyle area, followed by two minute cusps, paracone and metacone, and lingually a protocone area but without a concrete cusp.

\section{Mandible (Fig. 1B; Table 1)}

The corpus is long and low with a straight ventral border, the height below the premolars being marginally lesser than that below the molar (Table 1). There is a straightened dentary symphyseal angle $\left(115^{\circ}\right)$ lower than those of most of the extant felids and close to those of Neofelis Gray, 1867 and of the machairodont Promegantereon Kretzoi, 1938, $117^{\circ}$ and $118^{\circ}$ respectively (see Christiansen 2006). There is a large diastema from the canine to the $\mathrm{p} 3(13 \mathrm{~mm})$. The top of the ascending ramus is broken out but was probably not very high. The masseteric fossa is deep. The condyle is located lower than in extant genera. The mandibular foramen opens below the diastema.

\section{Lower dentition (Fig. 1B; Table 1)}

None of the incisors is preserved. The axis of the root of the canine is close to the vertical line and its length is $26.3 \mathrm{~mm}$. The crown is slightly backwardly curved with two faces: a flattened lingual one limited anteriorly by a ridge running from the top to the basis and distally by another ridge displaying small crenulations and another face extending over the whole buccal side and, mesially, turning to the lingual side. The $\mathrm{p} 1$ and $\mathrm{p} 2$ are absent. The $\mathrm{p} 3$ is high, relatively short, and almost symmetrical, despite a small pacd, a buccal discrete cingulum and a basal bulge along the lingual basis. The $\mathrm{p} 4$ is far larger than p3 and separated from it by $2 \mathrm{~mm}$; its main cuspid is high and flat with two accessory cuspids, the distal one being the largest. There is no lingual cingulum but a buccal one is present, mesially faint and distally thicker. The $\mathrm{m} 1$ is typical of felid, with a paraconid slightly smaller and lower than the protoconid, the lingual valley between these cuspids being deep and widely open. There is no metaconid but a very small trenchant talonid with a low mesio-distal occlusal ridge. A subtle but complete buccal cingulum extends along the buccal side.

\section{Postcranium (Tables 2-7)}

Most of the postcranial bones are fragmentary. The epiphyses of long bones in particular are not preserved or only partially; when preserved, long bone epiphyses are found isolated, disconnected from the diaphysis and may be gnawed by porcupines. Metapodials epiphyses are fused, however. This pattern of preservation and the light wearing of the fully erupted permanent dentition indicate that TM 112-00-99 is a young adult individual. 

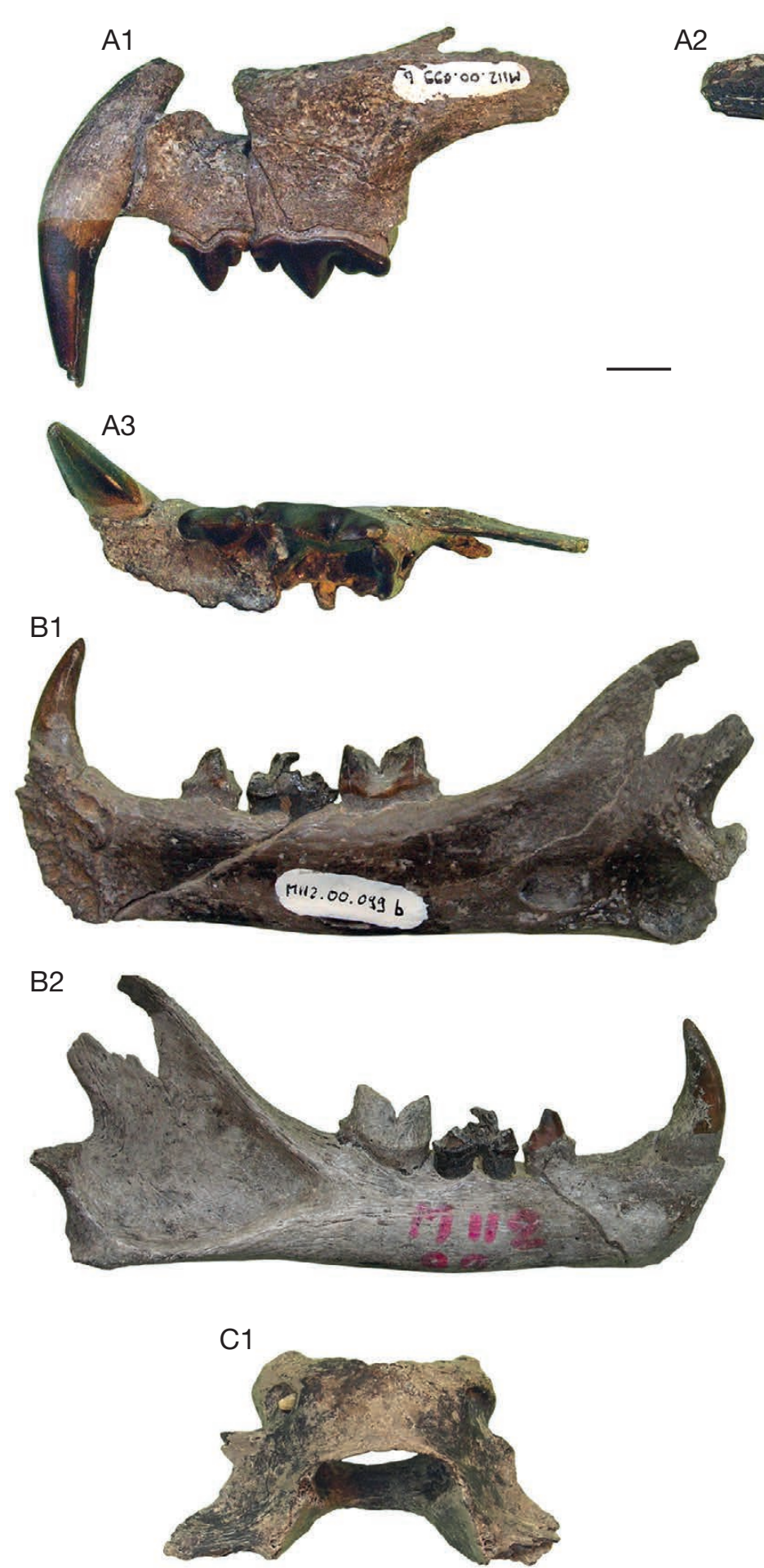

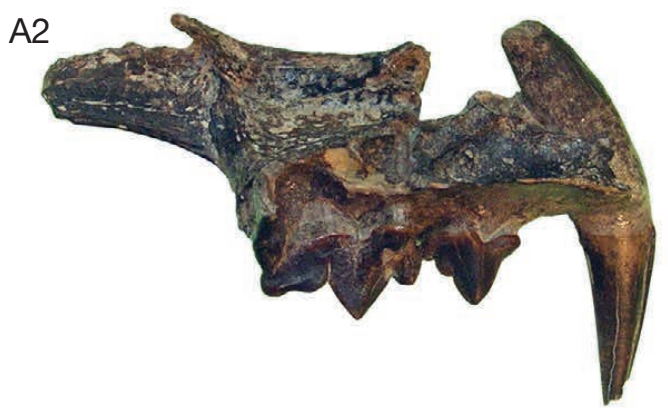

D

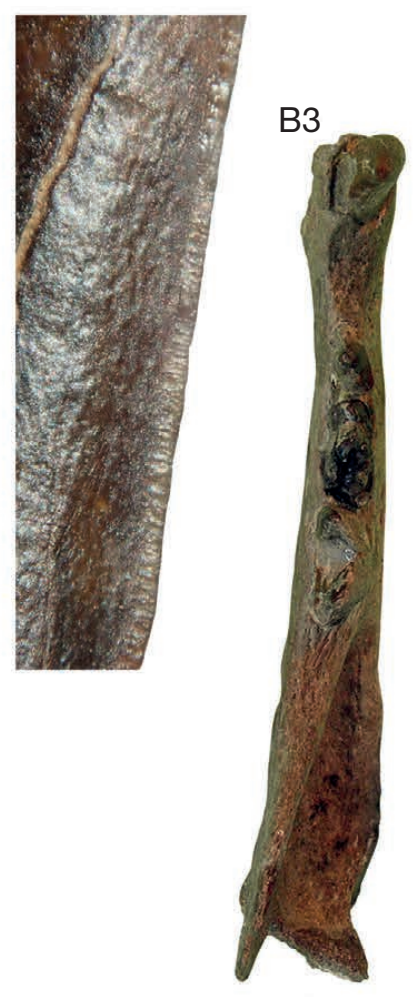

C2

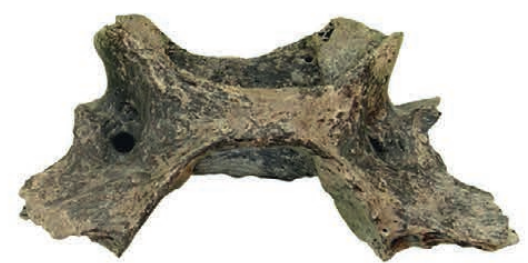

FIG. 1. - Tchadailurus adei n. gen., n. sp., TM 112-00-99, from Toros Menalla. Left maxilla with C-M1 in labial (A1), lingual (A2), and occlusal (A3) views; right hemimandible with c-m1 in lingual (B1), labial (B2), and occlusal (B3) views; fragmentary atlas in dorsal (D1) and ventral (D2) views. Scale bar: 10 mm.

Vertebrae (Fig. 1C; Tables 2, 3). Vertebrae of TM 112-00-99 are poorly preserved. Only the atlas, another cervical (probably a $3^{\text {rd }}$ or $4^{\text {th }}$ one), one lumbar and 22 caudals are mostly complete and worth mentioning. The atlas preserves the articular surfaces and the body, and only the base of the transverse processes or wings. The body is very short ventrally, since its ventral length $(7.5 \mathrm{~mm})$ is $c .46 \%$ of its dorsal length $(16 \mathrm{~mm})$.
On the ventral part of the body, just behind the alar notch, which is not pronounced, there is a deep elliptic fossa in which two transverse foramina are present. The cranialmost opens in the vertebral foramen, while the caudalmost is a short canal passing through the base of the transverse processes to open caudally. The ventral and dorsal tubercles are absent. The lateral vertebral foramina are located craniolaterally on the dorsal part 


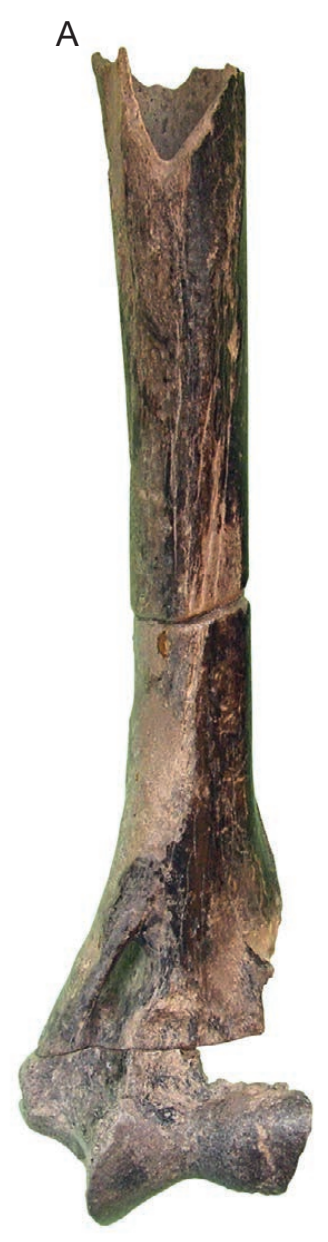

\section{B1}

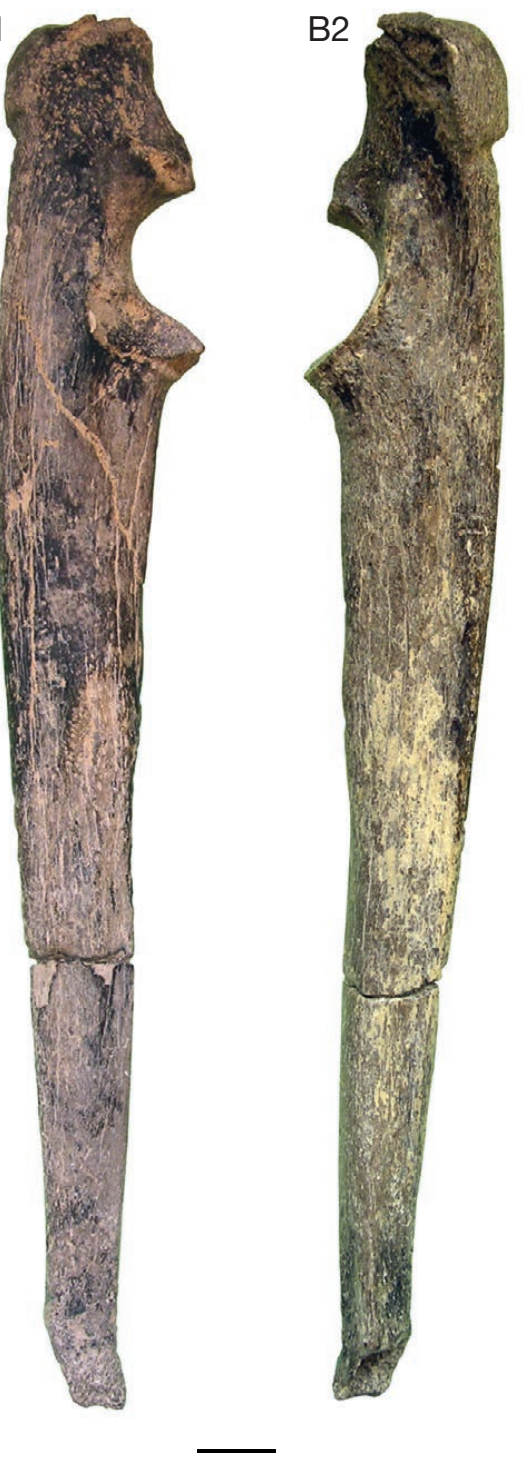

D1

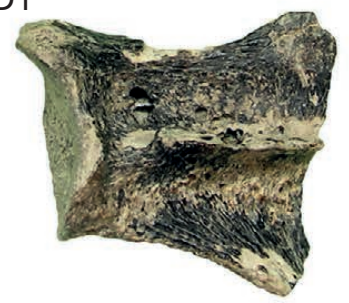

D2

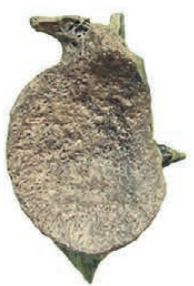

E1

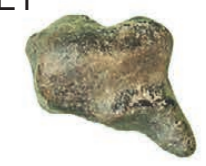

E3

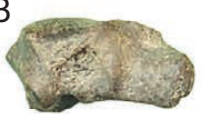

B3
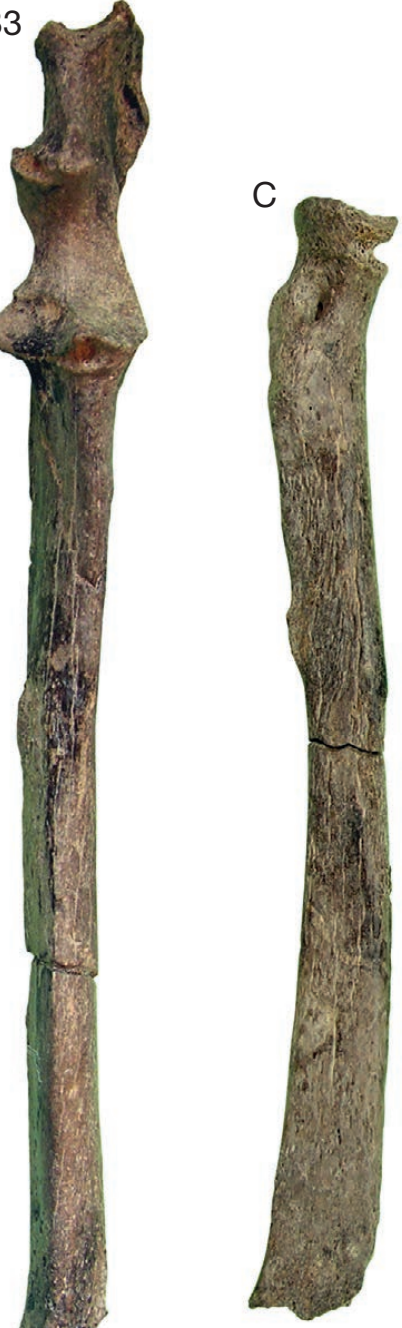

G

E2
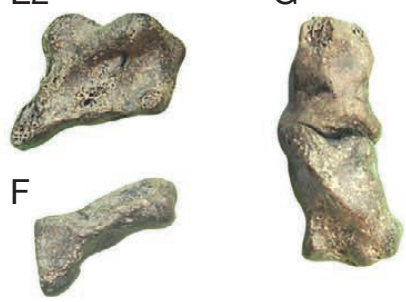

FIG. 2. - Tchadailurus adei n. gen., n. sp., TM 112-00-99, from Toros Menalla. Fragment of left humerus in anterio view (A); subcomplete right ulna in lateral (B1), medial (B2), and anterior (B3) views; subcomplete left radius in medial view (C); proximal fragment of left scapula in lateral (D1) and proximal (D2) views; left scapholunar in proximal (E1), distal (E2), and posterior (E3) views; right pisiform in lateral view (F); articulated right Mc I and first phalanx of digit I in anterior view (G). Scale bar: $10 \mathrm{~mm}$.

of the body. The other cervical vertebra lacks the neural and transverse processes. It has a long long body, relatively longer than any post-axis cervical of modern felids except Leptailurus serval in which we observe that C3, and C4 to a lesser extent, have a relatively long body. A single incomplete lumbar of TM 112-00-99 is available. It is laterally compressed, most of the body and the transverse processes are not preserved. Ten caudal vertebrae are more or less well preserved. We compared their morphology with those of Neofelis nebulosa, Lynx lynx and Leptailurus serval to locate them along the tail. We do not see any morphological difference. However, based on their morphology and body length we posit that TM had a tail certainly longer than that of Lynx lynx or Leptailurus serval but shorter than that of Neofelis nebulosa. 
TABLE 2. - Measurements in mm of caudal (Cd) body length of Tchadailurus adei n. gen., n. sp. (TM 112-00-99) compared to several extant medium-sized Felinae. Rank of the caudals of TM 112-00-99 were inferred based on comparative anatomy.

\begin{tabular}{lccccc}
\hline & $\begin{array}{c}\text { N. } \\
\text { nebulosa }\end{array}$ & L. serval & L. lynx & L. pardalis & $\begin{array}{c}\text { TM 112- } \\
\mathbf{0 0 9}\end{array}$ \\
\hline Cd1 & 14 & 11.1 & 12 & 11.9 & 14 \\
Cd2 & 16 & 9.6 & 11 & 12.2 & 17 \\
Cd3 & 18 & 8.8 & 11.5 & 12.7 & - \\
Cd4 & 20 & 8.7 & 12.2 & 14.8 & 19.8 \\
Cd5 & 24.4 & 12 & 14.1 & 17.4 & 20.5 \\
Cd6 & 27.8 & 16.5 & 15.6 & 20.7 & 23 \\
Cd7 & 31.3 & 19.1 & 18.2 & 23.1 & - \\
Cd8 & 34.1 & 20.5 & 18.6 & 23.7 & 24 \\
Cd9 & 36.3 & 22 & 16.8 & 23.3 & - \\
Cd10 & 37.4 & 22.4 & 15 & 22.6 & - \\
Cd11 & 37.6 & 21.5 & 13.7 & 21.7 & - \\
Cd12 & 37.5 & 20.7 & 12.5 & 20.5 & - \\
Cd13 & 36.9 & 19.3 & 11 & 18.7 & - \\
Cd14 & 36.4 & 18.9 & 10.2 & 17 & - \\
Cd15 & 35.3 & 15.8 & - & 15.4 & - \\
Cd16 & 33.3 & 14.2 & - & 14 & - \\
Cd17 & 31.1 & - & - & 12.6 & - \\
Cd18 & 28.6 & - & - & 10.2 & - \\
Cd19 & 26.7 & - & - & 8.1 & - \\
Cd20 & 24 & - & - & - & - \\
Cd21 & 22.1 & - & - & - & - \\
Cd22 & 19.7 & - & - & - & - \\
\hline & & & & &
\end{tabular}

Scapula (Fig. 2D: Table 3). Only a proximal fragment of the right scapula, including the base of the spine, is preserved. The glenoid cavity is shallow and roughly piriform in shape. Its medial rim is rounded, while its lateral rim is concavoconvex. The coracoid process is thin and approximately $7-\mathrm{mm}$ long (though it is probably not fully preserved); it is oriented medially and proximally. The facet for the $m$. biceps brachii is small. The neck of the scapula is not pronounced.

Long bones of forelimb (Table 3). None of the long bones of the forelimb is completely preserved. Only the distal two-thirds of the left diaphysis and the distal half of the right humerus are preserved, though none of the distal epiphyses is complete (Fig. 2A). The shaft is robust and laterally compressed, being $23 \mathrm{~mm}$ long and $16 \mathrm{~mm}$ wide across the deltoid tuberosity. The medial supracondylar ridge is pronounced but not much developed medially. The medial epicondyle is incompletely preserved, but was probably triangle-shaped. Although its distal part is not preserved, the lateral epicondyle was probably not much laterally expanded.

The radius (Fig. 2C) and ulna (Fig. 2B) are robust and have a typical felid morphology. The available fragments of the left and right ulna allow to have a nearly complete view of the anatomy of this bone in TM 112-00-99. The proximal twothirds of the shaft are laterally compressed, but its distal third is robust, triangular in section. The right olecranon is almost complete; the anterior part of its proximal face is marked by a wide and deep fossa bordered by two tubercles; the tip of the lateral tubercle is broken off but was probably lower than the medial tubercle. The caudal face of the olecranon is wide and expands medially (area of insertion for the large head of the $m$. triceps brachii). The radius has a craniocaudally

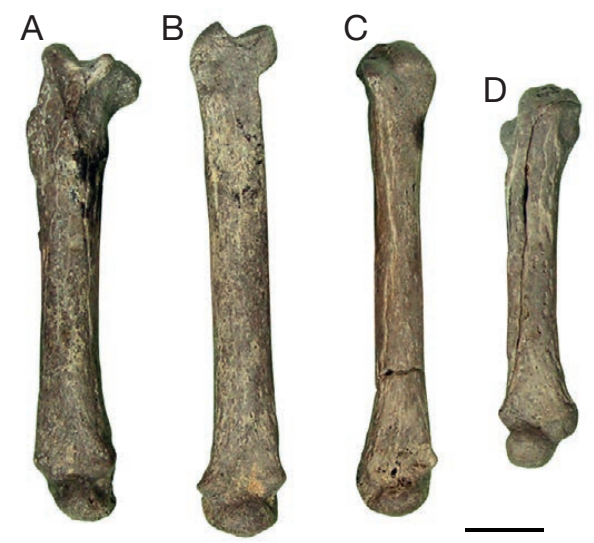

FIG. 3. - Tchadailurus adei n. gen., n. sp., TM 112-00-99, from Toros Menalla. Left metacarpals in dorsal view: Mc II (A), Mc III (B), Mc IV (C), and Mc V (D). Scale bar: $10 \mathrm{~mm}$.

compressed and bended (concave caudally) diaphysis, which is larger distally than proximally; the bicipital process is well marked. The epiphyses are incompletely preserved but the articular surfaces look very similar to those of modern felids.

Carpals (Table 4). Autopodial elements are the best preserved in TM 112-00-99. Carpals include the scapholunar, the pisiform, the hamate and the trapezium. The scapholunar (Fig. 2E) has a quadrangular proximal articular surface that is well convex dorsopalmarly and transversely elongated. As is typical in felids the posteromedial part is concave and bordered by a low lip. Its palmar tubercle is long and projected mediopalmarly. The pisiform (Fig. 2F) is long and possess robust extremities. The distal end has an elliptical shape, with a long axis (mediolateral) which is perpendicular to the long axis (dorsopalmar) of the proximal epiphysis. The hamate is a narrow and tall bone. It has a triangular distal articulation and a narrow, concavoconvex proximal articular surface. The articulation for the pyramidal is convex in its proximal part but slightly concave in its distal part. The trapezium is a small arched bone, dorsopalmarly elongated. It is much wider proximally than distally. The articulation for the Mc I is curved and slightly concave.

Metacarpals (Table 4). The metacarpals are robust and short (Fig. 3A-D). They do not display anatomical peculiarities, with the notable exception of the Mc I, which is extremely short and wide (Fig. 2G). The articular surface for the trapezium expands on half of the length; and it is concave in its proximal part. The palmar face of the base is marked by a low keel that articulates with the proximal phalanx of the first digit (Fig. 2G). This phalanx is also characteristic and unlike the other proximal phalanges. It is wide and short, although it is nearly $90 \%$ of the Mc I length. Other phalanges were found isolated so that it is not easy to assign them to a digit. Phalanges of the manus tend to be more gracile than those of the pes, however. TM 112-00-99 includes nine proximal phalanges in addition to those of the first digit, 11 medial phalanges, and 6 distal phalanges. The latter phalanges are not well preserved but one of them is much larger than any other and might be the distal phalanx of the first digit of the manus. 
TABLE 3. - Measurements in mm of the atlas, scapula and long bones of the forelimb of Tchadailurus adei n. gen., $\mathrm{n}$. sp. (TM 112-00-99) compared to several extant medium-sized Felinae. Symbol: *, estimate. Abbreviations: Dia, diameter; ML, mediolateral; dist, distal; art, articulation; prox, proximal; DV, dorsoventral; max, maximal; cran, cranial; coron, coronoid process of the ulna; Sp. no., specimen collection number. Extant specimens are from MNHN-ZM-(MO) collections. See Material and methods for additional abbreviations.

\begin{tabular}{|c|c|c|c|c|c|c|c|c|c|c|c|}
\hline \multirow[b]{2}{*}{ Sp. no. } & & \multirow{2}{*}{$\begin{array}{c}\text { T. adei } \\
\text { n. gen., } \\
\text { n. sp. } \\
\text { TM 112- } \\
\text { 00-99 }\end{array}$} & \multicolumn{3}{|c|}{$\begin{array}{c}\text { Prionailurus viverrinus } \\
\text { (Bennett, 1833) }\end{array}$} & \multicolumn{2}{|c|}{$\begin{array}{l}\text { Puma concolor } \\
\text { (Linnaeus, 1771) }\end{array}$} & \multicolumn{2}{|c|}{$\begin{array}{c}\begin{array}{c}\text { Lynx lynx } \\
\text { (Linnaeus, 1758) }\end{array} \\
\end{array}$} & \multicolumn{2}{|c|}{$\begin{array}{c}\text { Leopardus pardalis } \\
\text { (Linnaeus, 1758) }\end{array}$} \\
\hline & & & $\begin{array}{c}2015- \\
1300\end{array}$ & $1953-866$ & $\begin{array}{c}1884- \\
1170\end{array}$ & $\begin{array}{r}2016- \\
1669\end{array}$ & $\begin{array}{l}1993- \\
4625\end{array}$ & $\begin{array}{l}1994- \\
2443\end{array}$ & $1972-84$ & $2005-282$ & 2013-33 \\
\hline \multirow[t]{2}{*}{ Atlas } & Max W cran art & 38.6 & 29 & 33.5 & 33 & - & - & 38 & - & 33 & 31.2 \\
\hline & HDV & 24.5 & 17.5 & 19 & 19.2 & - & - & 20.5 & - & 18.2 & 18.4 \\
\hline \multirow[t]{3}{*}{ Scapula } & Dia AP prox art & 29 & 20.1 & 23.3 & 22.7 & 34.2 & 39.5 & 28.1 & 25.2 & 20.2 & 20.5 \\
\hline & Dia ML prox art & 19.4 & 11.7 & 14 & 15 & 23.5 & 28.5 & 17.6 & 16.5 & 13.6 & 13.6 \\
\hline & Dia AP neck & $27^{*}$ & 18.9 & 19.7 & 20.2 & 30.7 & - & 24.9 & 21.4 & 16.9 & 17.7 \\
\hline Ulna & AP Dia coron & 26.4 & 18 & - & 21 & 31 & 33.6 & 26.5 & 24 & 19 & 17.5 \\
\hline \multirow[t]{3}{*}{ Radius } & AP Dia dist art & 14.4 & 8.5 & - & 10.7 & 15.5 & 14.8 & 11.7 & 12 & 9.1 & 9.3 \\
\hline & ML Dia dist art & 20 & 12.7 & - & 13.5 & 24 & 22.6 & 18 & 17 & 14.1 & 12.4 \\
\hline & & \multicolumn{5}{|c|}{$\begin{array}{c}\text { Pardofelis } \\
\text { temminckii } \\
\text { (Vigors \& } \\
\text { Horsfield, 1827) } \\
\end{array}$} & \multicolumn{4}{|c|}{$\begin{array}{c}\text { Neofelis nebulosa } \\
\text { (Griffith, 1821) }\end{array}$} & $\begin{array}{c}\text { Panthera } \\
\text { pardus } \\
\text { (Linnaeus, } \\
\text { 1758) } \\
\end{array}$ \\
\hline \multicolumn{2}{|l|}{ Sp. no. } & 1927-1786 & 1963-75 & $1913-470$ & & $1-293$ & 1961-217 & $1980-16$ & 1971-86 & $1992-3$ & 1904-305 \\
\hline \multirow[t]{2}{*}{ Atlas } & Max W cran art & - & - & 31.8 & & .4 & 34.8 & 41.1 & - & 40.2 & 46.3 \\
\hline & H DV & - & - & 20.5 & & .5 & 21 & 23.5 & - & 22.3 & 26.8 \\
\hline \multirow[t]{3}{*}{ Scapula } & Dia AP prox art & - & 22 & 21.3 & & - & 22 & 28.3 & 22.5 & - & 35 \\
\hline & Dia ML prox art & - & 16.4 & 13.6 & & - & 13.5 & 19.8 & 14.6 & - & 25 \\
\hline & Dia AP neck & - & 19.8 & 20.5 & & - & 18.9 & 24.2 & 19 & - & 30.6 \\
\hline Ulna & AP Dia coron & 17.5 & 23 & 18.4 & & - & 18.2 & 25.3 & 20 & - & 33 \\
\hline \multirow[t]{2}{*}{ Radius } & AP Dia dist art & 8 & 11.4 & 9.6 & & - & 11 & 13.5 & - & - & - \\
\hline & ML Dia dist art & 14 & 15.7 & 14.3 & & - & 16.3 & 20.5 & - & - & - \\
\hline
\end{tabular}

Pelvis (Fig. 4A). The right part of the pelvis preserves most of the ilium, the acetabulum, and the cranial part of the ischium. The ilium wing is not very expanded and the body not pronounced. Dorsally, the ischial spine is pronounced and the insertion area for the $m$. gemellus caudalis very well defined along the dorsal border of the lesser ischiatic notch. The preserved dorsal margin of the obturator foramen suggests it was probably long, with a minimum of $42-\mathrm{mm}$ craniocaudal diameter. The iliopubic eminence is distinct.

Femur. The right femur, which is the best preserved, includes the diaphysis of which the lesser trochanter is not preserved, the cranial half of the distal epiphysis and the (isolated) greater trochanter. The diaphysis has an elliptic cross-section, being slightly craniocaudally compressed. In the distal epiphysis the lateral condyle is larger than the medial one, the intercondylar fossa is wide, and the facet for the articulation of the right fabella (sesamoid of the lateral head of $m$. gastrocnemius) is oriented lateral and slightly proximal.

Patella (Table 5). The patella is an elliptic bone, with a pointed distal end. The cranial face is overall convex, while the articular surface for the femur is proximodistally slightly concave (especially proximally) and mediolaterally convex.

Tibia. Tibiae are documented mostly by their epiphyses. The proximal epiphysis does not show any particularity. The medial articular facet of the distal epiphysis for the talus is not very deep and and the medial malleolus does not extant far distally. On the mediocaudal face of the epiphysis there is a marked, proximodistally oriented malleolar groove for the tendon of $m$. flexor digitorum longus.

Tarsals (Table 5). The astragalus is subcomplete, lacking only the proximalmost part of the medial malleolaris facet and the ventral rim of the head (Fig. B). The body is quadrate in shape. The head is distomedially projected and it has a long neck; the navicular facet was probably wider than high. This facet is not connected to the middle (or medial) facet for the calcaneus. The plantar (or lateral) facet for calcaneus is strongly concave and plantolaterally oriented. The lateral process (see Evans 1993: fig. 4-113) is poorly developed.

Both calcanei are present in the material, but the right one is better preserved (Fig. 4C). The bone is overall narrow and the tuber calcanei is robust and mediolaterally thick. The extremity of the tuber is wider, and the medial process is the most prominent. The plantar surface of the sustentaculum tali displays a marked and wide groove over which the tendon of the $m$. flexor hallucis longus glides. The lateral surface of the calcaneus is occupied by a wide depressed area for the insertion of the $m$. quadratus plantae which extends from the distal border to the mid-length of the tuber calcanei. Dorsal to the proximal part of this area, there is another marked, though much smaller, area for the attachment of the short part of the lateral collateral ligament. Nearly at the distalmost rim of the lateral face, there is a small, laterally expanded tubercle, grooved 


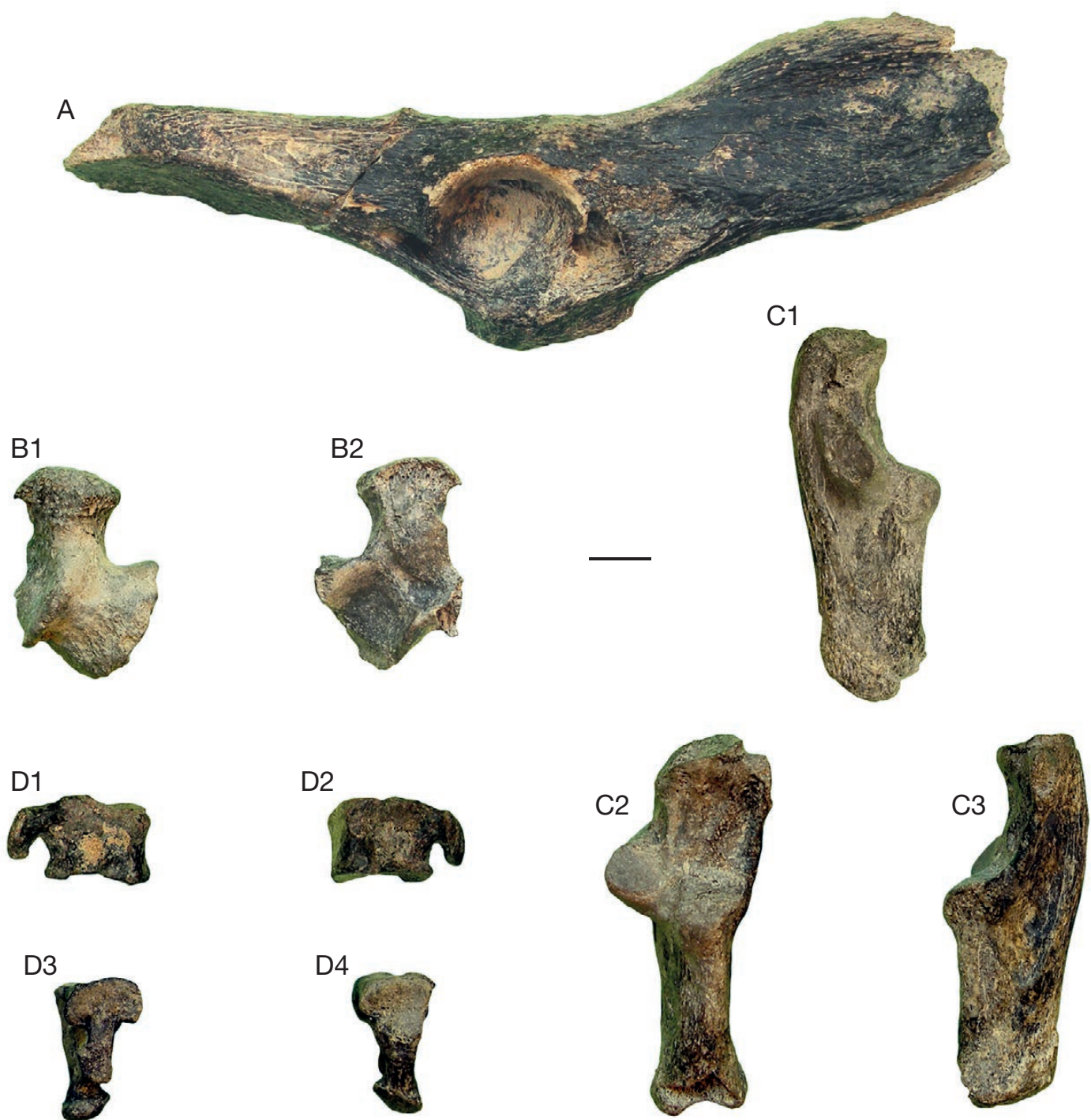

FIG. 4. - Tchadailurus adei n. gen., n. sp., TM 112-00-99, from Toros Menalla. Fragmentary right pelvis in lateral view (A); right astragalus in dorsal (B1) and ventral (B2) views; right calcaneus in medial (C1), dorsal (C2), and lateral (C3) views; left lateral cuneiform in medial (D1), lateral (D2), proximal (D3), and distal (D4) views. Scale bar: $10 \mathrm{~mm}$.

in its lateral face, on which the long part of the lateral collateral ligament attaches. The cuboid facet is oriented distomedially.

Both cuboids are present and incomplete, in particular the distal facet is not entirely preserved. The bone is proximodistally tall. Its proximal facet is rectangular, transversely expanded, and sightly convex. The tuberosity of the cuboid is thick and crosses obliquely the plantar face. The groove for the $m$. peroneus longus is deep and well marked.

The intermediate and lateral cuneiforms are well preserved. The intermediate cuneiform is a small, elliptic bone, with the two nearly flattened facets. The lateral cuneiform is very much larger (Fig. 4D); it has a triangular proximal facet; the distal facet is typically T-shaped, with a plantar part on which the lateral rim is longer and more rectilinear than the medial rim. The plantar tubercle of the lateral cuneiform extends from the plantar rim of the proximal facet and is oriented plantarly, with a much thickened inclined distally tip.
Metatarsals (Table 5). The metatarsals are rather well preserved (Fig. 5A), with the exception of the base of the Mt V. The most robust and straight is the Mt III whereas the Mt II and $\mathrm{Mt}$ IV have a curved shaft. $\mathrm{Mt} \mathrm{V}$ is the most gracile. The metatarsals are much longer than the metacarpals and have a slightly small robustness index with the notable exception of the Mt III.

\section{COMPARISONS \\ Dentition}

The extant felids differ from TM 112-00-99 by several morphological characters, particularly the shape of the upper canines whose crowns have generally a more rounded section without distal striations and the shape of the lower canines without the tiny distal crenulations. Most extant genera have an upper P2. TM 112-00-99 does not belong to any of the few Miocene African felid taxa (Werdelin \& Peigné 2010), which are much larger in size and have more marked machairodontine features. 
TABLE 4. - Measurements in mm of the carpals and metacarpals of Tchadailurus adei $\mathrm{n}$. gen., $\mathrm{n}$. sp. (TM 112-00-99) compared to several extant medium-sized Felinae. Abbreviations: Dia, diameter; ML, mediolateral; AP, anteroposterior; PD, proximodistal; dist, distal; art, articulation; prox, proximal; DV, dorsoventral; min, minimal; max, maximal; cran, cranial; trap, trapezium; Sp. no., specimen collection number. Extant specimens are from MNHN-ZM-(MO) collections. See Material and methods for additional abbreviations.

\begin{tabular}{|c|c|c|c|c|c|c|c|c|c|c|c|c|c|c|c|c|c|c|}
\hline \multirow[b]{2}{*}{ Sp. no. } & & \multirow{2}{*}{$\begin{array}{c}\begin{array}{c}\text { T. adei } \\
\text { n. gen., } \\
\text { n. sp. }\end{array} \\
\text { TM112 } \\
-00-99\end{array}$} & \multirow{2}{*}{ 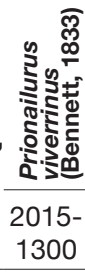 } & \multicolumn{2}{|c|}{$\begin{array}{c}\text { Prionailurus } \\
\text { bengalensis } \\
\text { (Kerr, 1792) }\end{array}$} & \multicolumn{2}{|c|}{$\begin{array}{c}\text { Puma } \\
\text { concolor } \\
\text { (Linnaeus, } \\
\text { 1771) }\end{array}$} & \multicolumn{2}{|c|}{$\begin{array}{c}\text { Lynx lynx } \\
\text { (Linnaeus, } \\
\text { 1758) }\end{array}$} & \multicolumn{2}{|c|}{$\begin{array}{c}\text { Leopardus } \\
\text { pardalis } \\
\text { (Linnaeus, } \\
\text { 1758) }\end{array}$} & \multicolumn{3}{|c|}{$\begin{array}{c}\text { Leptailurus } \\
\text { serval } \\
\text { (Schreber, 1776) }\end{array}$} & \multicolumn{4}{|c|}{$\begin{array}{c}\text { Neofelis nebulosa } \\
\text { (Griffith, 1821) }\end{array}$} \\
\hline & & & & $\begin{array}{l}1924- \\
1025\end{array}$ & $\frac{A}{13112}$ & $\begin{array}{c}2016- \\
1669\end{array}$ & $\begin{array}{l}1993- \\
4625\end{array}$ & $\begin{array}{l}1994- \\
2443\end{array}$ & 84 & 282 & 33 & 1786 & $\begin{array}{l}963 \\
75\end{array}$ & 470 & & $\begin{array}{l}980 \\
16\end{array}$ & 86 & 3 \\
\hline nah & $\begin{array}{l}\text { Dia ML } \\
\text { Dia AP } \\
\text { H PD } \\
\text { ML art dist } \\
\text { AP art dist }\end{array}$ & $\begin{array}{l}20 \\
18.2 \\
12.3 \\
18.5 \\
13.7\end{array}$ & $\begin{array}{l}11.7 \\
11 \\
7 \\
10.6 \\
8.4\end{array}$ & $\begin{array}{r}13.5 \\
11.5 \\
8.5 \\
12.5 \\
8.7\end{array}$ & $\begin{array}{l}- \\
- \\
- \\
- \\
-\end{array}$ & $\begin{array}{l}22.4 \\
18.5 \\
14.1 \\
22 \\
15\end{array}$ & $\begin{array}{l}24 \\
19.5 \\
15 \\
21.6 \\
15.7\end{array}$ & $\begin{array}{l}19 \\
16 \\
10.7 \\
17.5 \\
12.1\end{array}$ & $\begin{array}{l}20 \\
15.1 \\
10.1 \\
17 \\
12\end{array}$ & $\begin{array}{c}13 \\
12 \\
8.2 \\
12 \\
9.2\end{array}$ & $\begin{array}{r}12.8 \\
11.6 \\
7.3 \\
11.6 \\
8.7\end{array}$ & $\begin{array}{c}13 \\
10.6 \\
8.3 \\
11.4 \\
8\end{array}$ & $\begin{array}{l}- \\
- \\
- \\
- \\
-\end{array}$ & $\begin{array}{l}- \\
- \\
- \\
-\end{array}$ & $\begin{array}{c}17 \\
13 \\
8.8 \\
14 \\
9.2\end{array}$ & $\begin{array}{l}19 \\
17.3 \\
11.7 \\
17.5 \\
11.6\end{array}$ & $\begin{array}{l}- \\
- \\
- \\
-\end{array}$ & $\begin{array}{l}18.3 \\
16.3 \\
10.6 \\
17 \\
12 \\
\end{array}$ \\
\hline 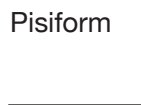 & $\begin{array}{l}\mathrm{L} \\
\text { Dia max prox } \\
\text { Dia min prox }\end{array}$ & $\begin{array}{l}22.1 \\
11 \\
7.6\end{array}$ & $\begin{array}{c}13.6 \\
6.8 \\
4\end{array}$ & $\begin{array}{c}14.8 \\
7.4 \\
4\end{array}$ & $\begin{array}{l}- \\
- \\
-\end{array}$ & $\begin{array}{r}22.6 \\
11.6 \\
7.5\end{array}$ & $\begin{array}{r}23.2 \\
12.3 \\
7.8\end{array}$ & $\begin{array}{c}18.1 \\
9.5 \\
6\end{array}$ & $\begin{array}{l}18 \\
10.3 \\
6\end{array}$ & $\begin{array}{l}13 \\
7.3 \\
4.3\end{array}$ & $\begin{array}{c}12.4 \\
6.4 \\
4\end{array}$ & $\begin{array}{r}12.3 \\
6.7 \\
4.1\end{array}$ & $\begin{array}{l}- \\
- \\
-\end{array}$ & $\begin{array}{l}- \\
- \\
-\end{array}$ & $\begin{array}{r}14.2 \\
8.6 \\
4.7\end{array}$ & & $\begin{array}{l}- \\
- \\
-\end{array}$ & $\begin{array}{l}- \\
- \\
-\end{array}$ \\
\hline $\mathrm{m}$ & $\begin{array}{l}\text { Dia AP } \\
\text { W ML } \\
\text { H PD }\end{array}$ & $\begin{array}{l}14 \\
10 \\
14.8\end{array}$ & $\begin{array}{l}8.2 \\
5.6 \\
7.6\end{array}$ & $\begin{array}{l}8.7 \\
6.4 \\
8.3\end{array}$ & $\begin{array}{l}- \\
- \\
-\end{array}$ & $\begin{array}{l}15 \\
10 \\
15\end{array}$ & $\begin{array}{l}16 \\
10.6 \\
15.3\end{array}$ & $\begin{array}{c}12.4 \\
9 \\
12\end{array}$ & $\begin{array}{r}12.4 \\
8.6 \\
11.9\end{array}$ & $\begin{array}{l}9.5 \\
6 \\
9.3\end{array}$ & 8.5 & $\begin{array}{l}7.6 \\
5.7 \\
9\end{array}$ & $\begin{array}{l}- \\
- \\
-\end{array}$ & $\begin{array}{l}- \\
- \\
-\end{array}$ & $\begin{array}{r}11.8 \\
6.9 \\
9.7\end{array}$ & $\begin{array}{r}14 \\
8.7 \\
11.9\end{array}$ & $\begin{array}{l}- \\
- \\
-\end{array}$ & $\begin{array}{r}13.6 \\
8.6 \\
11.7 \\
\end{array}$ \\
\hline & & $\begin{array}{l}8.5 \\
8.9\end{array}$ & $\begin{array}{l}5 \\
5.3\end{array}$ & $\begin{array}{l}8.6 \\
5.6 \\
6\end{array}$ & $\begin{array}{l}- \\
- \\
-\end{array}$ & $\begin{array}{l}8.7 \\
9.4\end{array}$ & $\begin{array}{l}- \\
- \\
-\end{array}$ & $\begin{array}{r}11.7 \\
6.5 \\
6.8\end{array}$ & $\begin{array}{l}6.5 \\
8\end{array}$ & $\begin{array}{l}- \\
- \\
-\end{array}$ & & $\begin{array}{l}5.4 \\
5.4\end{array}$ & $\begin{array}{l}- \\
- \\
-\end{array}$ & $\begin{array}{l}- \\
- \\
-\end{array}$ & $\begin{array}{l}9.1 \\
6 \\
5.2 \\
\end{array}$ & $\begin{array}{l}8.7 \\
6.3\end{array}$ & $\begin{array}{l}- \\
- \\
-\end{array}$ & $\begin{array}{l}- \\
- \\
-\end{array}$ \\
\hline 1 & $\begin{array}{l}\mathrm{L} \\
\text { Dia ML prox } \\
\text { Lart trap } \\
\text { Dia ML prox/L } \\
\text { Lart trap/L }\end{array}$ & $\begin{array}{c}21.8 \\
13.6 \\
11 \\
0.62 \\
0.50\end{array}$ & $\begin{array}{l}13.9 \\
6.8 \\
8 \\
0.49 \\
0.58 \\
\end{array}$ & $\begin{array}{l}16 \\
7.8 \\
7.5 \\
0.49 \\
0.47 \\
\end{array}$ & $\begin{array}{l}11.5 \\
5 \\
4.6 \\
0.43 \\
0.40\end{array}$ & $\begin{array}{c}24.8 \\
13.3 \\
10.5 \\
0.54 \\
0.42 \\
\end{array}$ & $\begin{array}{c}24.8 \\
13.2 \\
8.6 \\
0.53 \\
\quad 0.35 \\
\end{array}$ & $\begin{array}{c}18.4 \\
9.5 \\
8.3 \\
0.52 \\
0.45 \\
\end{array}$ & $\begin{array}{c}20.2 \\
10.4 \\
8.5 \\
0.51 \\
0.42 \\
\end{array}$ & $\begin{array}{l}15.4 \\
8.4 \\
7 \\
0.55 \\
0.45 \\
\end{array}$ & $\begin{array}{l}14.2 \\
7.4 \\
6.7 \\
0.52 \\
0.47 \\
\end{array}$ & $\begin{array}{l}17 \\
7.6 \\
6.8 \\
0.45 \\
0.40 \\
\end{array}$ & $\begin{array}{l}19.6 \\
8 \\
7.8 \\
0.41 \\
0.40 \\
\end{array}$ & $\begin{array}{l}19.5 \\
7.3 \\
7.4 \\
0.37 \\
0.38 \\
\end{array}$ & $\begin{array}{l}16.5 \\
7.7 \\
7.3 \\
0.47 \\
0.44 \\
\end{array}$ & $\begin{array}{l}21.3 \\
11.5 \\
11 \\
0.54 \\
0.52 \\
\end{array}$ & \begin{tabular}{|l|}
17.8 \\
8.9 \\
8.8 \\
0.50 \\
0.49 \\
\end{tabular} & $\begin{array}{l}- \\
- \\
- \\
-\end{array}$ \\
\hline Mc II & $\begin{array}{l}\mathrm{L} \\
\text { Dia ML prox } \\
\text { Dia ML 1/2L } \\
\text { Dia AP 1/2L } \\
\text { L/Dia ML 1/2L }\end{array}$ & $\begin{array}{c}62.4 \\
10.2 \\
7.7 \\
7.7 \\
8.10\end{array}$ & $\begin{array}{l}35.8 \\
6 \\
4.1 \\
3.9 \\
8.73\end{array}$ & $\begin{array}{r}38.6 \\
6.2 \\
4.4 \\
3.6 \\
8.77\end{array}$ & $\begin{array}{l}- \\
- \\
- \\
-\end{array}$ & $\begin{array}{c}67.8 \\
11.2 \\
6.1 \\
8.8 \\
11.11 \\
\end{array}$ & $\begin{array}{c}68.4 \\
10.8 \\
6.2 \\
7 \\
11.03\end{array}$ & $\begin{array}{l}57 \\
8.7 \\
6 \\
6.3 \\
9.50\end{array}$ & $\begin{array}{l}63.3 \\
9.5 \\
5 \\
5.4\end{array}$ & $\begin{array}{l}37.7 \\
6 \\
5 \\
4.4 \\
7.54\end{array}$ & $\begin{array}{l}36 \\
6.1 \\
4 \\
3.5 \\
9.00\end{array}$ & $\begin{array}{c}47.3 \\
6.5 \\
3.7 \\
4.2 \\
12.78 \\
\end{array}$ & $\begin{array}{l}- \\
- \\
- \\
-\end{array}$ & $\begin{array}{l}- \\
- \\
- \\
-\end{array}$ & $\begin{array}{l}7 \\
5.2 \\
4.7 \\
6.92 \\
\end{array}$ & $\begin{array}{l}40.3 \\
9.5 \\
6 \\
5.6 \\
6.72 \\
\end{array}$ & $\begin{array}{l}37 \\
7.2 \\
5.3 \\
4.7 \\
6.98 \\
\end{array}$ & $\begin{array}{l}39.7 \\
8.3 \\
6.4 \\
5.5 \\
6.20 \\
\end{array}$ \\
\hline & $\begin{array}{l}\mathrm{L} \\
\text { Dia ML prox } \\
\text { Dia ML 1/2L } \\
\text { Dia AP 1/2L } \\
\text { L/Dia ML 1/2L }\end{array}$ & $\begin{array}{l}67 \\
12.4 \\
7.5 \\
6.5 \\
8.93\end{array}$ & $\begin{array}{l}39.9 \\
8 \\
3.8 \\
3.9 \\
10.50\end{array}$ & $\begin{array}{l}43.2 \\
9 \\
4.4 \\
3.5 \\
9.82\end{array}$ & $\begin{array}{l}- \\
- \\
- \\
- \\
-\end{array}$ & $\begin{array}{l}76 \\
14.5 \\
7 \\
7.4 \\
10.86\end{array}$ & $\begin{array}{c}15.3 \\
7.1 \\
6 \\
10.56\end{array}$ & $\begin{array}{l}11.7 \\
6.8 \\
5.9 \\
9.41\end{array}$ & $\begin{array}{l}74.7 \\
11 \\
5.8 \\
5.8 \\
12.88\end{array}$ & $\begin{array}{l}8.2 \\
5.1 \\
4.4 \\
8.53\end{array}$ & $\begin{array}{c}42.1 \\
7.9 \\
4 \\
3.7 \\
10.53\end{array}$ & $\begin{array}{c}8.7 \\
4.2 \\
4.3 \\
12.86\end{array}$ & $\begin{array}{l}- \\
- \\
- \\
- \\
-\end{array}$ & $\begin{array}{l}- \\
- \\
- \\
- \\
-\end{array}$ & $\begin{array}{l}44.4 \\
10 \\
5 \\
4.7 \\
8.88\end{array}$ & $\begin{array}{c}47.5 \\
11.5 \\
6.1 \\
5.6 \\
7.79\end{array}$ & $\begin{array}{l}43.5 \\
10 \\
5.2 \\
4.5 \\
8.37\end{array}$ & $\begin{array}{c}46.4 \\
11.4 \\
6.2 \\
5.4 \\
7.48\end{array}$ \\
\hline IV & $\begin{array}{l}\mathrm{L} \\
\text { Dia ML prox } \\
\text { Dia ML 1/2L } \\
\text { Dia AP 1/2L } \\
\text { L/Dia ML 1/2L }\end{array}$ & $\begin{array}{l}62.3 \\
10 \\
6.5 \\
6.3 \\
9.58\end{array}$ & $\begin{array}{r}36.2 \\
6.5 \\
3.6 \\
4.1 \\
10.06 \\
\end{array}$ & $\begin{array}{c}39.8 \\
6.7 \\
3.5 \\
3.8 \\
11.37\end{array}$ & $\begin{array}{l}- \\
- \\
- \\
- \\
-\end{array}$ & $\begin{array}{c}11 \\
11 \\
6 \\
7.3 \\
11.83 \\
\end{array}$ & $\begin{array}{c}10.8 \\
6.5 \\
6.3 \\
10.89\end{array}$ & $\begin{array}{c}5 y .0 \\
7.8 \\
5.9 \\
5.6 \\
10.08\end{array}$ & $\begin{array}{c}9 \\
5.5 \\
6.4 \\
12.98 \\
\end{array}$ & $\begin{array}{l}40.5 \\
7 \\
4.7 \\
4.5 \\
8.62\end{array}$ & $\begin{array}{l}38.4 \\
6.4 \\
4 \\
3.8 \\
9.68 \\
\end{array}$ & $\begin{array}{c}51.4 \\
6.1 \\
3.8 \\
4 \\
13.53 \\
\end{array}$ & $\begin{array}{l}- \\
- \\
- \\
- \\
-\end{array}$ & $\begin{array}{l}- \\
- \\
- \\
-\end{array}$ & $\begin{array}{l}43.5 \\
7.2 \\
4.9 \\
5.3 \\
8.88\end{array}$ & $\begin{array}{l}47.3 \\
9.2 \\
5.6 \\
5.7 \\
8.45 \\
\end{array}$ & $\begin{array}{l}42.1 \\
8 \\
4.4 \\
4.6 \\
9.70\end{array}$ & $\begin{array}{l}- \\
- \\
- \\
-\end{array}$ \\
\hline 2 & $\begin{array}{l}\mathrm{L} \\
\text { Dia ML 1/2L } \\
\text { Dia AP 1/2L } \\
\text { L/Dia ML 1/2L }\end{array}$ & $\begin{array}{l}50.5 \\
6 \\
5.9 \\
8.42\end{array}$ & $\begin{array}{c}28.7 \\
3.9 \\
3.7 \\
7.36\end{array}$ & $\begin{array}{c}32 \\
3.8 \\
3.2 \\
8.42\end{array}$ & $\begin{array}{l}- \\
- \\
-\end{array}$ & $\begin{array}{c}58 \\
5.7 \\
6.5 \\
10.18\end{array}$ & $\begin{array}{c}59.4 \\
6.7 \\
6.7 \\
8.87\end{array}$ & $\begin{array}{c}47.8 \\
5.6 \\
5.2 \\
8.54\end{array}$ & $\begin{array}{c}58.8 \\
5.3 \\
5.2 \\
11.09\end{array}$ & $\begin{array}{l}33 \\
4.9 \\
4.2 \\
6.73\end{array}$ & $\begin{array}{l}31.2 \\
3.8 \\
3.7 \\
8.21\end{array}$ & $\begin{array}{c}43.7 \\
3.6 \\
4 \\
-\end{array}$ & $\begin{array}{l}- \\
- \\
- \\
-\end{array}$ & $\begin{array}{l}- \\
- \\
-\end{array}$ & $\begin{array}{l}33.2 \\
4.8 \\
4.7 \\
6.92\end{array}$ & $\begin{array}{c}37.1 \\
6.5 \\
5.4 \\
5.71\end{array}$ & $\begin{array}{c}34.1 \\
5 \\
4.4 \\
6.82\end{array}$ & $\begin{array}{l}- \\
- \\
-\end{array}$ \\
\hline
\end{tabular}

Thus the comparisons will be focused on the late Miocene, medium-sized felid genera of Eurasia.

Abelia Kretzoi, 1938 includes two species. The type species A. pentelica Kretzoi, 1938 is based on a single specimen from the late Miocene of Pikermi (Greece) figured by Abel (1922: 136, fig. 125) under the name Felis leiodon Weithofer, 1888. It is a left hemi-mandible with $\mathrm{p} 3-\mathrm{m} 1$ housed in the Vienna University. It differs from TM 112-00-99 by the less steep symphysis, the shorter diastema, the convex ventral border of the mandible, the deeper corpus, p3 longer relatively to $\mathrm{p} 4$, with a lower and asymmetric crown (mesial half shorter than the distal one) with a developed buccal cingulum; $\mathrm{p} 4$ and $\mathrm{m} 1$ lower relatively to the length, $\mathrm{p} 4$ with a developed buccal cingulum. The second species, $A$. pontopersica (Kretzoi, 1929), will be discussed below.

Dromopanthera Kretzoi, 1929 was erected for Felis leiodon. We shall not discuss the validity of the genus and the species which are sometimes considered as synonyms of other taxa but we only examine the characters of the holotype and single specimen, a mandible with the canine and $\mathrm{p} 4-\mathrm{m} 1$ from the late Miocene of Pikermi (Greece) figured by Weithofer (1888: pl. 9, fig. 8). Compared to TM 112-00-99, that specimen is more thickset, with two large mental foramina, $\mathrm{p} 4$ and $\mathrm{m} 1$ are longer and lower with more developed cingula, p3, from its 
alveoli, was more robust, far longer and the diastema between p3 and the canine is very short.

Fortunictis Pons-Moyá, 1987, with the only species F. acerensis Pons-Moyá, 1987, is far larger (50\%) than TM 112-00-99 and displays more marked machairodont features.

Metailurus Zdansky, 1924 is based on the type species M. major Zdansky, 1924 from the late Miocene of China. The large size $(\mathrm{Lm} 1=23.6-24.4 \mathrm{~mm}$; LP4 = 26-31 mm $)$ and the typical machairodont characters separate that species from TM 112-00-99. Metailurus ultimus Li, 2014 was established on specimens from the Pliocene firstly attributed to $M$. major (Teilhard de Chardin \& Leroy 1945); it reaches almost the same dimensions as this species and differs greatly from TM 112-00-99. We can say almost the same for Metailurus hengduanshanensis Zong, Chen, Huang, $\mathrm{Xu}, 1996$ from the late Pliocene whose size is only a little smaller than that of M. major. Another species, Metailurus minor Zdansky, 1924 was described from the same layers as $M$. major. This species has a more complicated history. It has been often synonymized with a species from the late Miocene of Pikermi (Greece) called Machairodus parvulus Hensel, 1863 and later linked to Metailurus. The generic name of the species minor has been recently discussed (Spassov \& Geraads 2015). These authors think that the skull of M. minor (Zdansky 1924: pl. 30, figs 1-3) is too different from that of $M$. major to keep both species in a same genus. Therefore they proposed to classify the species minor to the new genus Yoshi Spassov \& Geraads, 2015 that they created for a skull coming from the late Miocene of FYROM (Yoshi garevskii Spassov \& Geraads, 2015). We do not discuss here the taxonomy of the genus Metailurus, and we compare TM 112-00-99 to each species.

"Machairodus" parvulus Hensel, 1863 from the late Miocene (MN 12) of Pikermi (Greece) is founded on a piece of mandible with p3-p4, the latter being incomplete. It differs from the Chadian carnivoran by the larger symphyseal angle, the presence of a mandibular flange, the presence of two mental foramina, the more mesial being much large, and the more massive and larger p3.

Yoshi minor (or parvulus) from the late Miocene of China is larger, the upper canine is longer for the same height, more flattened and a cast of the type specimen does not seem to display striations on the distal crest; the diastema between $\mathrm{C}$ and $\mathrm{P} 3$ is shorter; the mesial border of $\mathrm{P} 3$ is almost straight and the distal turning up of the cingulum is very small; the parastyle of P4 is relatively smaller and the metastyle shorter. Yoshi garevskii is known from a complete skull whose mandible is attached to the calvarium. The diagnosis of the genus is based essentially on the features of the skull, the teeth being characterized as "Upper canines short without crenulations but with an anterior keel located mesially rather than mesiolingually, lingual surface almost flat or slightly convex, buccal one slightly flattened to convex. P3 and p3 without mesial accessory cusp and cuspid, $\mathrm{m} 1$ with distinct talonid". Except the height of the upper canine which is relatively smaller than that of TM 112-00-99, most of the characters are present in the Chadian specimen. The authors describe a specimen from Kalimantsi (Bulgaria) as Yoshi cf. minor (Spassov \& Geraads
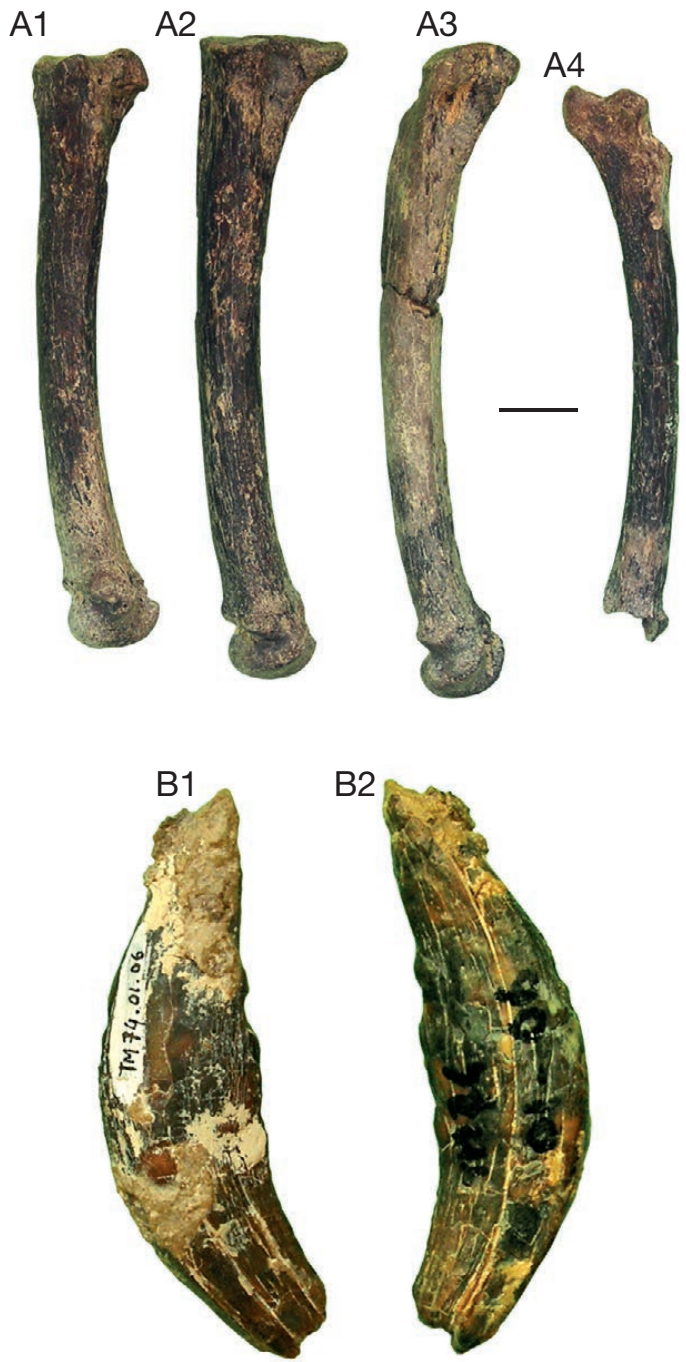

FIG. 5. - Tchadailurus adei n. gen., n. sp., TM 112-00-99, from Toros Menalla. Metatarsals: right Mt II (A1) and Mt III (A2) in medial view; left Mt IV lateral view (A3) and subcomplete left Mt V in anterior view (A4). Dinofelis sp., TM 74-0106, from Toros Menalla: left upper canine in lateral (B1) and medial (B2) views. Scale bar: $10 \mathrm{~mm}$.

2015: fig. 6). The dentition displays a greater size than that of TM 112-00-99, an upper canine mesio-distally longer but relatively less high, a shorter diastema, a less marked parastyle of P4, a shorter mandibular diastema, less high lower premolar, and a convex ventral border on the corpus. The overall shape of that mandible is slightly similar to that of the mandible figured by Abel (1922: 136, fig. 125) as Felis leiodon and named Abelia pentelica Kretzoi, 1938. Metailurus mongoliensis Colbert, 1939 comes from the locality of Tung Gur, Mongolia, at the limit middle-late Miocene. It differs from TM 112-00-99 in its larger size, more compressed p3 and $\mathrm{p} 4, \mathrm{p} 3$ longer relatively to $\mathrm{p} 4$ and $\mathrm{m} 1, \mathrm{p} 4$ shorter relatively to $\mathrm{m} 1, \mathrm{p} 3$ with an aacd, and a pacd more developed and followed by a small bead, 44 with an aacd as large as the pacd, an enlarged main cuspid, $\mathrm{m} 1$ with a protoconid clearly higher than the paraconid and a more reduced vestigial talonid, less steep anterior border of the symphysis, beginning of flange, corpus higher, especially in the anterior portion, 
with a convex ventral border, large mental foramen situated beneath the mesial root of $\mathrm{p} 3$. The shape of the corpus and that of the $\mathrm{m} 1$ would justify, may be, a new genus but Kretzoi has forgotten that species!

Miopanthera Kretzoi, 1938 is based on Pseudaelurus lorteti Gaillard, 1899 from the late middle Miocene (MN 7-8) of La Grive Saint-Alban, France. Pseudaelurus lorteti is smaller than TM 112-00-99 (LP4 = $16 \mathrm{~mm} ; \mathrm{Lm} 1=13 \mathrm{~mm})$, the metastyle of P4 is relatively shorter, $\mathrm{p} 2$ is present and the talonid of $\mathrm{m} 1$, although reduced, is greater. We may say the same for "Felis" pamiri Ozansoy, 1965 now attributed to Miopanthera (Geraads \& Peigné 2017). Pseudaelurus quadridentatus (Blainville, 1843) was of similar size to that of TM 112-00-99; its mandible shows a same angular chin, as in many machairodontines. However the Chadian species differs in having, for example, a (buccolingually) thinner I3, a thicker $\mathrm{m} 1$, no P2/ $\mathrm{p} 2$, and a longer metastyle on P4.

Paramachairodus Pilgrim, 1913 is based on P. orientalis (Kittl, 1887), the type specimen of which is a well preserved maxilla (Kittl 1887: pl. 14, figs 1-5) coming from the late Miocene of Maragha (Iran). It is larger than TM 112-00-99, the upper canines are also striated but more flattened, I3 is smaller relatively to I2, the metastyle of $\mathrm{P} 4$ is slightly less developed, and the lower canine is more reduced. In the same plate, a piece of mandible (Kittl 1887: fig. 6) is figured by Kittl as a different species that he called Felis cf. brevirostris, probably because he considered it was too small to fit the maxilla. Kretzoi (1929) attributed this fossil to Pseudaelurus? pontopersicus and later (Kretzoi 1938) to Abelia pontopersica (Kretzoi, 1929). Nevertheless if we compare the length of P4 in the maxilla and that of $\mathrm{m} 1$ in the mandible, the index ( $\mathrm{Lm} 1 /$ LP4) $\times 100$ reaches 64 . This number seems low insofar this index varies commonly from 70 to 86 in single individuals of extant felids. But it is only 66 in TM 112-00-99 and can be as low as 52 if measured on different individuals. So, this index does not prevent the Maragha maxilla and mandible figured by Kittl for belonging to the same species. The lower dentition differs from that of TM 112-00-99 by a relatively more reduced canine with crenulations and narrower cheek teeth. Paramachairodus schlosseri (Weithofer, 1888) and Paramachairodus hungaricus (Kormos, 1911) differ from the type species of the genus only by minute details. These species display another difference with TM 112-00-99, that is, the presence of two large mental foramina. Paramachairodus pilgrimi Kretzoi, 1929 includes only the specimen GSI-140, from the late Miocene of Hasnot (Punjab). This is a mandible with a broken off canine, p3-p4 and partially broken off $\mathrm{m} 1$. It differs from TM 112-00-99 by the massive corpus and the relatively larger p3.

Parapseudaelurus Kretzoi, 1929 was created for the new species P. osborni from the late Miocene locality Csâkvar, Hungary based on an isolated $\mathrm{P} 4$. The tooth, with a mesially situated salient protocone, does not correspond to the morphology of TM 112-00-99. We follow Spassov \& Geraads (2015: 53) who wrote, in comparison to a FYROM fossil, that "[...] this species has a mesially located, narrow and salient protocone [...]" and "that generic identity can be excluded". We can write the same for TM 112-00-99.
Pontosmilus Kretzoi, 1929 was established with 'Machairodus' orientalis Kittl, 1887 as type species. However, it is admitted that Pilgrim (1915), when creating Paramachairodus with the two species orientalis and schlosseri had implicitly chosen the former as a type. So, Pontosmilus, devoid of a type species, is not a valid genus. Nevertheless Kretzoi (1929) admitted another species, Pontosmilus indicus Kretzoi, 1929, for a mandible figured by Pilgrim (1915: pl. 5, fig. 2) under the name Paramachairodus cf. schlosseri. This specimen differs clearly from TM 112-00-99 by the larger p3 (from alveoli) and the mental flange of the mandible.

Promegantereon is based on Felis ogygia (Kaup, 1832) of which the type specimen is a piece of mandible with p3-p4 coming from the early late Miocene (Vallesian) of Eppelsheim, Germany. This poor type material was completed by Beaumont (1975) who added some remains from the same area and especially by Salesa et al. $(2003,2005)$ with the material from Batallones-1 (Spain) although the material was, in 2003, assigned to the genus Paramachairodus. Promegantereon ogygia differs from TM 112-00-99 in the greater size, the low $\mathrm{p} 3$, the less reduced talonid of $\mathrm{m} 1$, the mandibular condyle at level of the cheek teeth, an upper canine more compressed at the neck but without striations (compression index $=61$ ), and a P4 with a relatively larger parastyle and protocone less backwardly situated.

Propontosmilus sivalensis (Lydekker, 1877) was established by Kretzoi (1929) for a mandible named Pseudailurus sivalensis by Lydekker (1877) and figured later (1884: pl. 44, fig. 7) with only a piece of $\mathrm{m} 1$ and alveoli of other teeth. Suffice to say that it differs from TM 112-00-99 in a larger p3 (based on the alveoli), the probable presence of a vestigial p2, two mental foramina and an incipient mandibular flange. Another species, P. matthewi Kadic \& Kretzoi, 1930 is known by a single $\mathrm{m} 1$, which is larger than that of TM 112-00-99 ( $\mathrm{L}=22 \mathrm{~mm})$ and "carrying a well developed metaconid" (Kretzoi 1951: 409) unlike TM 112-00-99.

Protamphimachairodus Kretzoi, 1929 had been erected for "Machairodus" maximiliani Zdansky, 1924. Nonetheless, the criteria used by Kretzoi to separate the genus are not obvious and the species has been attributed to Paramachairodus by most of following authors (Pilgrim 1931; Beaumont 1978; Salesa et al. 2003, 2005, 2010a) and considered as a different species of that genus because its larger size or as a synonym of Paramachairodus orientalis. In all cases, it is different from TM 112-00-99 by the larger size, the preparastyle, longer metastyle and more distally situated protocone of $\mathrm{P} 4$.

Sivaelurus Pilgrim, 1913, whose type and unique species is $S$. chinjiensis (Pilgrim, 1910), comes from the probably middle Miocene of Chinji (Punjab, India). It is known by a piece of maxilla with the broken off canine, alveolus of P2 and P3-M1. It has the same size as TM 112-00-99 (length of P4 $=20.6 \mathrm{~mm}$ ) but differs by the canine without distal ridge, the presence of $\mathrm{P} 2$ and the absence of diastema, $\mathrm{P} 3$ shorter with a smaller aac, and the shorter metastyle of P4.

Sivafelis Pilgrim, 1932 and Sivapanthera Kretzoi, 1929 are both based on species coming from the Plio-Pleistocene 
TABLE 5. - Measurements of hind limb bones of Tchadailurus adei n. gen., n. sp. (TM 112-00-99) compared to several extant medium-sized Felinae. Abbreviations: Dia, diameter; ML, mediolateral; AP, anteroposterior; PD, proximodistal; tuber, tuber calcanei; dist, distal; art, articulation; prox, proximal; Lat, lateral; cuneif, cuneiform; Int, intermediate; DV, dorsoventral; Lbase art dist, maximum length between the proximal epiphysis and the proximalmost point of the distal articulation; Sp. no., specimen collection number. Extant specimens are from MNHN-ZM-(MO) collections. See Material and methods for additional abbreviations.

\begin{tabular}{|c|c|c|c|c|c|c|c|c|c|c|c|c|c|c|c|}
\hline \multirow[b]{2}{*}{ Sp. no. } & & \multirow{2}{*}{$\begin{array}{c}\text { T. adei } \\
\text { n. gen., } \\
\text { n. sp. } \\
\text { TM } 112 \\
-00-99\end{array}$} & \multicolumn{2}{|c|}{$\begin{array}{l}\text { Prionailurus } \\
\text { viverrinus } \\
\text { (Bennett, } \\
\text { 1833) }\end{array}$} & \multirow{2}{*}{ 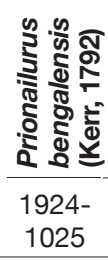 } & \multicolumn{2}{|c|}{$\begin{array}{c}\text { Puma } \\
\text { concolor } \\
\text { (Linnaeus, } \\
\text { 1771) }\end{array}$} & \multicolumn{2}{|c|}{$\begin{array}{c}\text { Lynx lynx } \\
\text { (Linnaeus, } \\
\text { 1758) }\end{array}$} & \multicolumn{2}{|c|}{$\begin{array}{c}\text { Leopardus } \\
\text { pardalis } \\
\text { (Linnaeus, } \\
\text { 1758) }\end{array}$} & \multirow{2}{*}{ 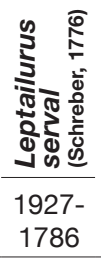 } & \multicolumn{3}{|c|}{$\begin{array}{c}\text { Neofelis nebulosa } \\
\text { (Griffith, 1821) }\end{array}$} \\
\hline & & & $\begin{array}{c}2015- \\
1300\end{array}$ & $\begin{array}{c}1884- \\
1170\end{array}$ & & $\begin{array}{c}2016- \\
1669\end{array}$ & $\begin{array}{l}1993- \\
4625\end{array}$ & $\begin{array}{l}1994- \\
2443\end{array}$ & $\begin{array}{c}1972- \\
84\end{array}$ & $\begin{array}{c}2005- \\
282\end{array}$ & $\begin{array}{c}2013- \\
33\end{array}$ & & $\begin{array}{c}1980- \\
16\end{array}$ & $\begin{array}{c}1971- \\
86\end{array}$ & $\begin{array}{c}1992- \\
3\end{array}$ \\
\hline Patella & $\begin{array}{l}\text { Dia ML } \\
\text { Dia PD }\end{array}$ & & $\begin{array}{l}- \\
-\end{array}$ & $\begin{array}{l}- \\
-\end{array}$ & $\begin{array}{l}- \\
-\end{array}$ & $\begin{array}{l}- \\
-\end{array}$ & $\begin{array}{l}- \\
-\end{array}$ & $\begin{array}{l}17 \\
27.6\end{array}$ & $\begin{array}{l}- \\
-\end{array}$ & $\begin{array}{l}11.2 \\
15.4\end{array}$ & $\begin{array}{l}11.4 \\
15.3\end{array}$ & $\begin{array}{l}11.5 \\
16.4\end{array}$ & $\begin{array}{l}17.5 \\
25.6\end{array}$ & $\begin{array}{l}14.3 \\
19.6\end{array}$ & $\begin{array}{l}- \\
-\end{array}$ \\
\hline Calcaneum & $\begin{array}{l}\mathrm{L} \\
\text { W ML } \\
\text { Dia ML tuber }\end{array}$ & $\begin{array}{l}60 \\
27 \\
15.2\end{array}$ & $\begin{array}{l}36.2 \\
15.5 \\
10\end{array}$ & $\begin{array}{l}41.5 \\
20 \\
10.8\end{array}$ & $\begin{array}{l}39.7 \\
18 \\
9.9\end{array}$ & $\begin{array}{l}65.5 \\
27.5 \\
16\end{array}$ & $\begin{array}{l}65.6 \\
28 \\
16.7\end{array}$ & $\begin{array}{l}50.8 \\
21.7 \\
12.6\end{array}$ & $\begin{array}{l}58.5 \\
25 \\
14\end{array}$ & $\begin{array}{l}39.4 \\
18 \\
9.9\end{array}$ & $\begin{array}{r}36.4 \\
17.3 \\
8.9\end{array}$ & $\begin{array}{l}40 \\
16 \\
10.7\end{array}$ & $\begin{array}{l}52.7 \\
24.7 \\
15.2\end{array}$ & $\begin{array}{l}45 \\
- \\
11.2\end{array}$ & $\begin{array}{l}49.5 \\
23.2 \\
13.3\end{array}$ \\
\hline Astragalus & $\begin{array}{l}\mathrm{L} \\
\mathrm{L} \text { condyle lat } \\
\mathrm{W} \mathrm{ML} \\
\text { Dia ML head } \\
\text { Dia DV head }\end{array}$ & $\begin{array}{r}30.3 \\
22.2 \\
29.5 \\
>17.2 \\
>11.5\end{array}$ & $\begin{array}{l}18.8 \\
14.1 \\
18 \\
10.1 \\
7.4\end{array}$ & $\begin{array}{l}20.5 \\
15.7 \\
20.2 \\
11.4 \\
9\end{array}$ & $\begin{array}{l}21.6 \\
16.3 \\
19 \\
11.4 \\
8\end{array}$ & $\begin{array}{l}32 \\
24.7 \\
30.6 \\
21 \\
15.3\end{array}$ & $\begin{array}{l}32.3 \\
25 \\
32.7 \\
18.4 \\
14\end{array}$ & $\begin{array}{l}24.8 \\
19.7 \\
25.5 \\
15.9 \\
11\end{array}$ & $\begin{array}{l}29.4 \\
20.5 \\
28 \\
17.3 \\
11.2\end{array}$ & $\begin{array}{l}23.8 \\
14.5 \\
20 \\
11.4 \\
7.4\end{array}$ & $\begin{array}{r}21.1 \\
14.5 \\
18.8 \\
10.3 \\
7.3\end{array}$ & $\begin{array}{l}22 \\
13.7 \\
19.6 \\
11.3 \\
8.5\end{array}$ & $\begin{array}{l}30.2 \\
24 \\
27.8 \\
15.7 \\
11.2\end{array}$ & $\begin{array}{l}26 \\
18.4 \\
- \\
13.6 \\
8.8\end{array}$ & $\begin{array}{l}29 \\
22.3 \\
26.4 \\
14.6 \\
10.5\end{array}$ \\
\hline Cub & $\begin{array}{l}\text { H PD } \\
\text { W ML } \\
\text { Dia AP } \\
\text { Dia AP art prox } \\
\text { Dia ML art prox }\end{array}$ & $\begin{array}{c}17.2 \\
14.4 \\
14.7 \\
9.2 \\
15 \\
\end{array}$ & $\begin{array}{l}11 \\
9.4 \\
8.7 \\
6.1 \\
9\end{array}$ & $\begin{array}{l}13 \\
11.5 \\
11 \\
7.2 \\
11\end{array}$ & $\begin{array}{l}- \\
- \\
- \\
-\end{array}$ & $\begin{array}{l}18 \\
15.5 \\
16.6 \\
15.5 \\
12\end{array}$ & $\begin{array}{l}18.4 \\
18 \\
16.4 \\
11.1 \\
14.5\end{array}$ & $\begin{array}{c}15.5 \\
14.2 \\
12.4 \\
9 \\
12.5\end{array}$ & $\begin{array}{l}17 \\
14 \\
14.7 \\
11.8 \\
13.9\end{array}$ & $\begin{array}{l}11 \\
10.5 \\
10 \\
7 \\
10\end{array}$ & $\begin{array}{r}10.5 \\
9.6 \\
9.7 \\
7.2 \\
10.1 \\
\end{array}$ & $\begin{array}{l}13.5 \\
11 \\
9.5 \\
9 \\
7.6\end{array}$ & $\begin{array}{c}16 \\
15 \\
12.8 \\
9 \\
15\end{array}$ & $\begin{array}{r}13.6 \\
13.6 \\
12.5 \\
8.8 \\
13.1 \\
\end{array}$ & $\begin{array}{r}14.7 \\
14.3 \\
12.5 \\
9.2 \\
14.5 \\
\end{array}$ \\
\hline Lat & $\begin{array}{l}\text { Dia AP } \\
\text { Dia ML } \\
\text { HPD } \\
\text { Dia AP art Mt III }\end{array}$ & $\begin{array}{l}23 \\
13 \\
12.4 \\
17.1\end{array}$ & $\begin{array}{c}13 \\
7 \\
7.8 \\
8.8\end{array}$ & $\begin{array}{r}15.3 \\
8.9 \\
8.1 \\
10.3\end{array}$ & $\begin{array}{l}- \\
- \\
- \\
-\end{array}$ & $\begin{array}{l}26.5 \\
14.5 \\
13.6 \\
18\end{array}$ & $\begin{array}{l}23.7 \\
13.7 \\
13 \\
16.3\end{array}$ & $\begin{array}{l}19.6 \\
11 \\
12 \\
13.4\end{array}$ & $\begin{array}{l}20.1 \\
12 \\
11.9 \\
15.6\end{array}$ & $\begin{array}{l}14 \\
7.7 \\
8 \\
9.7\end{array}$ & $\begin{array}{l}13.3 \\
8 \\
8 \\
9.4\end{array}$ & $\begin{array}{l}13.5 \\
8 \\
9 \\
9.4\end{array}$ & $\begin{array}{l}18.3 \\
11 \\
11 \\
13.3\end{array}$ & $\begin{array}{l}15.5 \\
9.5 \\
9 \\
-\end{array}$ & $\begin{array}{l}17.4 \\
10.6 \\
10.3 \\
12.8\end{array}$ \\
\hline Int cuneif & $\begin{array}{l}\text { Dia AP } \\
\text { H PD }\end{array}$ & $\begin{array}{l}11 \\
8.9\end{array}$ & $\begin{array}{l}- \\
-\end{array}$ & $\begin{array}{l}- \\
-\end{array}$ & $\begin{array}{l}- \\
-\end{array}$ & $\begin{array}{r}11.5 \\
6.5\end{array}$ & $\begin{array}{r}11.4 \\
7.7\end{array}$ & $\begin{array}{l}9.5 \\
7.1\end{array}$ & $\begin{array}{l}8.6 \\
7\end{array}$ & $\begin{array}{l}6.7 \\
4\end{array}$ & $\begin{array}{l}- \\
-\end{array}$ & $\begin{array}{l}6.6 \\
5.6\end{array}$ & $\begin{array}{l}9.8 \\
7\end{array}$ & $\begin{array}{l}- \\
-\end{array}$ & $\begin{array}{l}- \\
-\end{array}$ \\
\hline Mt II & $\begin{array}{l}\mathrm{L} \\
\text { Dia ML 1/2L } \\
\text { Dia AP 1/2L } \\
\text { L/Dia ML 1/2L }\end{array}$ & $\begin{array}{l}76.8 \\
7.8 \\
7.6 \\
9.85\end{array}$ & $\begin{array}{c}51.3 \\
4.6 \\
3.9 \\
11.15\end{array}$ & $\begin{array}{c}56.5 \\
5.3 \\
5.1 \\
10.66\end{array}$ & $\begin{array}{l}- \\
- \\
- \\
-\end{array}$ & $\begin{array}{l}83.9 \\
7 \\
7 \\
11.99\end{array}$ & $\begin{array}{c}85.5 \\
7.1 \\
6.4 \\
12.04\end{array}$ & $\begin{array}{c}78 \\
6.7 \\
5.9 \\
11.64\end{array}$ & $\begin{array}{c}92.5 \\
6.3 \\
5.5 \\
14.68\end{array}$ & $\begin{array}{l}49 \\
5.7 \\
4.5 \\
8.60\end{array}$ & $\begin{array}{r}49.5 \\
4.2 \\
3.5 \\
11.79\end{array}$ & $\begin{array}{c}69 \\
4.7 \\
4 \\
14.68\end{array}$ & $\begin{array}{l}54 \\
5.7 \\
5 \\
9.47\end{array}$ & $\begin{array}{c}50.4 \\
5 \\
4.4 \\
10.08\end{array}$ & $\begin{array}{l}52.7 \\
6.2 \\
5 \\
8.50\end{array}$ \\
\hline Mt III & $\begin{array}{l}\mathrm{L} \\
\text { Dia ML 1/2L } \\
\text { Dia AP 1/2L } \\
\text { L/Dia ML 1/2L }\end{array}$ & $\begin{array}{l}83.2 \\
11 \\
8 \\
7.56 \\
\end{array}$ & $\begin{array}{c}55.6 \\
5.4 \\
4.6 \\
10.30 \\
\end{array}$ & $\begin{array}{l}62.4 \\
6.3 \\
5 \\
9.90\end{array}$ & $\begin{array}{l}- \\
- \\
- \\
-\end{array}$ & $\begin{array}{c}94.8 \\
10.1 \\
8.2 \\
9.39 \\
\end{array}$ & $\begin{array}{c}96.3 \\
9.6 \\
7.9 \\
10.03 \\
\end{array}$ & $\begin{array}{c}85.5 \\
8.8 \\
6.6 \\
9.72 \\
\end{array}$ & $\begin{array}{r}101.3 \\
8.8 \\
6.9 \\
11.51 \\
\end{array}$ & $\begin{array}{l}54.4 \\
6.1 \\
5 \\
8.92 \\
\end{array}$ & $\begin{array}{c}54 \\
5 \\
4.1 \\
10.80 \\
\end{array}$ & $\begin{array}{c}74.5 \\
5.6 \\
4.4 \\
13.30 \\
\end{array}$ & $\begin{array}{l}60.5 \\
7 \\
6.2 \\
8.64\end{array}$ & $\begin{array}{c}56.3 \\
5.9 \\
4.8 \\
9.54\end{array}$ & $\begin{array}{l}59 \\
7 \\
5.5 \\
8.43 \\
\end{array}$ \\
\hline Mt IV & $\begin{array}{l}\mathrm{L} \\
\text { Dia ML 1/2L } \\
\text { Dia AP 1/2L } \\
\text { L/Dia ML 1/2L }\end{array}$ & $\begin{array}{c}84 \\
8.3 \\
7.8 \\
10.12 \\
\end{array}$ & $\begin{array}{l}- \\
4.7 \\
4.9 \\
-\end{array}$ & $\begin{array}{c}62.4 \\
5.5 \\
5.5 \\
11.35 \\
\end{array}$ & $\begin{array}{l}- \\
- \\
- \\
-\end{array}$ & $\begin{array}{l}- \\
- \\
- \\
-\end{array}$ & $\begin{array}{c}94.2 \\
8.2 \\
8.7 \\
11.49 \\
\end{array}$ & $\begin{array}{c}85.5 \\
7.2 \\
6.5 \\
11.88 \\
\end{array}$ & $\begin{array}{c}101 \\
7 \\
7.4 \\
14.43\end{array}$ & $\begin{array}{c}55.2 \\
5.5 \\
5 \\
10.04 \\
\end{array}$ & $\begin{array}{c}55 \\
4.3 \\
4.2 \\
12.79 \\
\end{array}$ & $\begin{array}{c}75.5 \\
5.1 \\
4.7 \\
14.80 \\
\end{array}$ & $\begin{array}{c}63.3 \\
6.6 \\
6.6 \\
9.59 \\
\end{array}$ & $\begin{array}{c}58 \\
5.2 \\
4.7 \\
11.15 \\
\end{array}$ & $\begin{array}{c}60.3 \\
6.2 \\
5.5 \\
9.73 \\
\end{array}$ \\
\hline Mt V & $\begin{array}{l}\text { Lbase art dist } \\
\text { Dia prox ML }\end{array}$ & $\begin{array}{l}70.3 \\
12.4\end{array}$ & $\begin{array}{r}48.7 \\
8.5\end{array}$ & $\begin{array}{r}54.4 \\
9.7\end{array}$ & $\begin{array}{r}49 \\
9\end{array}$ & $\begin{array}{l}74 \\
13.8\end{array}$ & $\begin{array}{l}78 \\
13.7\end{array}$ & $\begin{array}{l}70.5 \\
10.5\end{array}$ & $\begin{array}{l}88.5 \\
12.2\end{array}$ & $\begin{array}{r}47.4 \\
9.1\end{array}$ & $\begin{array}{r}47.1 \\
8.9\end{array}$ & $\begin{array}{c}66.8 \\
9\end{array}$ & $\begin{array}{l}51.3 \\
12.4\end{array}$ & $\begin{array}{l}47.3 \\
10.3\end{array}$ & $\begin{array}{l}50 \\
10.7\end{array}$ \\
\hline
\end{tabular}

of upper Siwalik. Both have robust mandibles with large p3 bearing aacd very different from that of TM 112-0099. Some researchers consider that these genera have some affinities with extant species (Olive 2006).

Sivasmilus copei Kretzoi, 1929 was established for a fragment of mandible from the lower Siwalik (Chinji) named Sivaelurus chinjiensis? by Pilgrim (1915: pl 6, fig 2). The tooth size corresponds to that of TM 112-0099, but the diastema is longer, the large mental foramen is situated lower and, especially, there is a clear mental flange. In fact, it seems that this mandible fits quite well the maxilla of Sivaelurus chinjiensis.

Stenailurus Crusafont-Pairo \& Aguirre, 1972 was created for the species S. teilhardi Crusafont-Pairo \& Aguirre,
1972, which is based on a piece of maxilla found in the late Miocene (Turolian) of Piera, Spain. It is larger than TM 112-00-99 and differs in the smaller size difference between I2 an I3, relatively larger upper canine, presence of P2, and more mesially situated protocone of $\mathrm{P} 4$.

\section{Postcranium}

The comparative sample include 20 specimens belonging to nine modern species (see Material and Methods) that represent seven of the eight clades of middle- to large-sized felids, defined as "lineages" in Johnson et al. (2006). Depending on the bone considered, TM 112-00-99 is comparable in size to $N$. nebulosa (for example, MNHN-ZM-1992-3; Lskull = 142.7), and slightly larger than Lynx lynx (for 
example, MNHN-ZM-MO-1994-2443; Lskull = 123.8; $\mathrm{Lm} 1=14.3)$. In addition compared to these species the anatomy of the postcranium of TM 112-00-99 is very similar and differs only in details. The most obvious difference with any of the modern species used here is the size and proportion of the $\mathrm{Mc} \mathrm{I}$ and, to a lesser extent, the size and proportion of the proximal phalanx of the same digit. The Mc I is relatively shorter and stronger (based on Prox W/ML ratio; Table 4) than in any modern felids, including Panthera spp. (average range is $0.49-0.52, \mathrm{~N}=$ 28; Salesa comm. pers.) and Acinonyx jubatus (Schreber, 1775) ( $\mathrm{m}=0.44, \mathrm{~N}=2$; Salesa comm. pers.). Actually, the proportions of the Mc I of TM 112-00-99 are similar to those found in the machairodontines Promegantereon ogygia $(\mathrm{m}=0.64$, range $=0.578-0.691, \mathrm{~N}=31 ;$ Salesa comm . pers.) and Pseudaelurus quadridentatus (0.59); in contrast these proportions differs from those of the Mc I of the feline Miopanthera lorteti $(\mathrm{m}=0.50$, range $=0.48-0.51$, $\mathrm{N}=4$ ) that is more gracile and similar to that of modern species. The associated first phalanx is also rather robust in TM 112-00-99. It is more robust (proximal width/total length ratio $=0.73$ ) than in most fossil and modern felids used in comparison (Table 6), and than those of Panthera Oken, 1816, Acinonyx Brookes, 1828, and Po ogygia $(\mathrm{m}=$ 0.66 , range $=0.61-0.74, \mathrm{~N}=37$; Salesa comm. pers.). The only exceptions in modern felids are Prionailurus viverrinus $(0.70)$ and Leopardus pardalis (range $=0.69-0.75$, $\mathrm{N}=2$ ). Based on maximal lengths, the proportion of the proximal phalanx of the first digit relative to the $\mathrm{Mc} \mathrm{I}$ is also a characteristic of TM 112-00-99 (L Ph I/L Mc I = 0.88 ) compared to modern felids (Table 6). We noticed that proportions and/or dimensions of the skeletal elements of TM 112-00-99 are somewhat different from those of modern felids. For example, measurements of some bones or part of bones of Lynx lynx (specimen MNHN-ZMMO-1994-2443), an individual with a Lm1 only slightly smaller than that of TM 112-00-99 are smaller (articulation of the scapula, distal articular surface of the radius, carpal and tarsal bones, metacarpals) or larger (e.g., patella, metatarsals) than in the Chadian specimen. Overall postcranial elements of TM 112-00-99 look more robust than their homologues in modern felids. This pattern is particularly true for long bones and metapodials but, again, this pattern suffers exceptions depending on bones or species. The metapodials of TM 112-00-99 show differences in proportions compared to those of modern felids. Their robustness (ratio of $\mathrm{L}$ to $\mathrm{ML} \mathrm{W}$ at mid-length of diaphysis; Tables 4, 5) is (much) greater than in Prionailurus Severtzov, 1858, Puma Jardine, 1834, Lynx, Leptailurus, similar to that in Leopardus pardalis (the two individuals of the species show a great variability in robustness of metapodials) and Neofelis nebulosa. The difference is particularly great with species such as Puma concolor and Leptailurus serval. There are some exceptions to this pattern. The most prominent seems to be the Mt III of TM 112-00-99, which is more robust than in any of the modern species used in comparison and which is the most robust of the
TM 112-00-99 metapodials. It is even more robust than in Promegantereon ogygia $(\mathrm{m}=8.08, \mathrm{~N}=22$; Salesa comm. pers.) but similar to that in Pseudailurus quadridentatus $(\mathrm{m}=7.7, \mathrm{~N}=2)$. Relative lengths of metapodials show interspecific differences (Table 7) but felids generally show a strong reduction of the lateral digits of the manus (Mc I, II and Mc V) and of the first digit of the pes (sometime lost), with total lengths decreasing as follows: $\mathrm{Mc}$ III $>\mathrm{Mc}$ $\mathrm{IV}>\mathrm{Mc}$ II $>\mathrm{Mc} \mathrm{V}>\mathrm{Mc}$ I. TM 112-00-99 differs a little from this pattern, with a Mc II slightly longer relative to the Mc III than in other species. The pattern is slightly different for metatarsals since TM 112-00-99 follows the general pattern observed in modern felids: $\mathrm{Mt} \mathrm{IV} \geq \mathrm{Mt} \mathrm{III}>\mathrm{Mt} \mathrm{V}>\mathrm{Mt} \mathrm{II}>\mathrm{Mt}$ I when present. Although not completely preserved the $\mathrm{Mt}$ $\mathrm{V}$ was probably longer than the Mt II in TM 112-00-99. There are intraspecific differences but in the context of the present study they are not worth mentioning.

\section{DisCUSSION}

TM 112-00-99 does not fit any known medium-sized felid. It displays some machairodont characters as flattened crown and distal striations of the upper canine, long metastyle of $\mathrm{P} 4$, shape of the mandible with a lowly located condyle, short and strong Mc I, and possible the robustness of the first phalanx associated with the Mc I. It constitutes a new taxon in the carnivoran fauna of Toros Menalla. Nevertheless, by its dimensions, it fits another specimen (SAM PQ-L 16055) from the early Pliocene locality of Langebaanweg, South Africa, figured as Felis aff. issiodorensis Croizet \& Jobert, 1828 by Hendey (1974). However, the lower canine of this specimen (Hendey 1974: fig. 33) displays a lateral groove, as in most of the extant species, which is lacking in the canines of TM 112-00-99. On the other hand, 'Felis' (Lynx) issiodorensis (Croizet \& Jobert, 1828) from the late Pliocene of the Montagne de Perrier (France) differs by the less reduced $\mathrm{p} 3$ which displays a developed aacd (Croizet \& Jobert 1828: pls 3, 5). Other remains from Les Etouaires, France (Kurtén 1978) indicate that the upper canine of this species is Lynx-like, without flattening and striations. Another lynx, Lynx thomasi Geraads, 1980, was described from a mandible coming from the middle Pleistocene of Morocco, Africa. The size is far smaller than that of TM 112-00-99, p3 is relatively more developed, the corpus thicker, the diastema short, the symphysis rounded and the canine more curved.

\section{Genus Dinofelis Zdansky, 1924}

TyPe SPECIES. - Dinofelis cristata (Falconer \& Cautley, 1836) by subsequent designation (Werdelin \& Lewis 2001).

\section{Dinofelis sp.}

Referred material From Toros Menalla. - TM 74-01-06, left upper canine.

LOCALITY. — TM 79, Toros Menalla, Chad.

Geological age. — Late Miocene; c. 7 Ma. 
TABLE 6. - Measurements in mm of the Mc I and its associated first phalanx of Tchadailurus adei n. gen., n. sp. (TM 112-00-99) compared to several extant medium-sized Felinae. Abbreviations: ML, mediolateral; prox, proximal; Sp. no., specimen collection number. Extant specimens are from MNHN-ZM-(MO) collections. See Material and methods for additional abbreviations.

\begin{tabular}{|c|c|c|c|c|c|c|c|c|c|c|c|c|c|c|}
\hline \multirow[b]{2}{*}{ Sp. no. } & \multirow{2}{*}{$\begin{array}{c}\begin{array}{c}\text { T. adei } \\
\text { n. gen., } \\
\text { n. sp. }\end{array} \\
\text { TM } 112 \\
-00-99\end{array}$} & \multirow{2}{*}{ 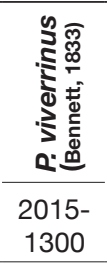 } & \multicolumn{2}{|c|}{$\begin{array}{c}\text { Prionailurus } \\
\text { bengalensis } \\
\text { (Kerr, 1792) }\end{array}$} & \multicolumn{2}{|c|}{$\begin{array}{c}\text { Puma concolor } \\
\text { (Linnaeus, } \\
1771)\end{array}$} & \multicolumn{2}{|c|}{$\begin{array}{c}\text { Lynx lynx } \\
\text { (Linnaeus, } \\
\text { 1758) }\end{array}$} & \multicolumn{2}{|c|}{$\begin{array}{c}\text { Leopardus } \\
\text { pardalis } \\
\text { (Linnaeus, } \\
1758 \text { ) }\end{array}$} & \multirow{2}{*}{ 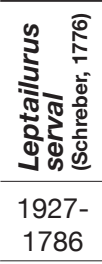 } & \multicolumn{3}{|c|}{$\begin{array}{c}\text { Neofelis nebulosa } \\
\text { (Griffith, 1821) }\end{array}$} \\
\hline & & & $\begin{array}{c}1924- \\
1025\end{array}$ & $\begin{array}{c}\text { A } \\
13112 \\
\end{array}$ & $\begin{array}{r}2016- \\
1669 \\
\end{array}$ & $\begin{array}{c}1993- \\
4625\end{array}$ & $\begin{array}{l}1994- \\
2443\end{array}$ & $\begin{array}{c}1972- \\
84\end{array}$ & $\begin{array}{c}2005- \\
282\end{array}$ & $\begin{array}{c}2013- \\
33\end{array}$ & & $\begin{array}{c}1961- \\
217\end{array}$ & $\begin{array}{c}1980- \\
16\end{array}$ & $\begin{array}{c}1971- \\
86\end{array}$ \\
\hline $\mathrm{McIL}$ & 21.8 & 13.9 & 16 & 11.5 & 24.8 & 24.8 & 18.4 & 20.2 & 15.4 & 14.2 & 17 & 16.5 & 21.3 & 17.8 \\
\hline $\begin{array}{l}\text { L I } \\
\text { W ML pro } \\
\text { W ML pro } \\
\text { L Ph I/L }\end{array}$ & $\begin{array}{l}19.1 \\
14 \\
0.73 \\
0.88\end{array}$ & $\begin{array}{c}10.7 \\
7.5 \\
0.70 \\
0.77\end{array}$ & $\begin{array}{c}11.6 \\
7.3 \\
0.63 \\
0.73\end{array}$ & $\begin{array}{l}8.4 \\
5.2 \\
0.62 \\
0.73\end{array}$ & $\begin{array}{l}20.6 \\
14 \\
0.68 \\
0.83\end{array}$ & $\begin{array}{c}20.6 \\
12.9 \\
0.63 \\
0.83\end{array}$ & $\begin{array}{c}15.2 \\
10.3 \\
0.68 \\
0.83\end{array}$ & $\begin{array}{l}17 \\
9.8 \\
0.58 \\
0.84\end{array}$ & $\begin{array}{c}11.2 \\
7.7 \\
0.69 \\
0.73\end{array}$ & $\begin{array}{l}10.2 \\
7.6 \\
0.75 \\
0.72\end{array}$ & $\begin{array}{c}10.7 \\
7.4 \\
0.69 \\
0.63\end{array}$ & $\begin{array}{l}12.8 \\
7.8 \\
0.61 \\
0.78\end{array}$ & $\begin{array}{l}17 \\
10.5 \\
0.62 \\
0.80\end{array}$ & $\begin{array}{l}15 \\
8.7 \\
0.58 \\
0.84\end{array}$ \\
\hline
\end{tabular}

TABLE 7. - Relative proportions (\%) of metapodial lengths in Tchadailurus adei n. gen., n. sp. (TM 112-00-99) compared to several extant medium-sized Felinae; for each species Mc and Mt III lengths are used as the reference (100\%) to calculate the relative proportion of the other metapodials; for the Mt V, we use the maximum length between the proximal epiphysis and the proximalmost point of the distal articulation (see Table 5), because the distal articulation is not completely preserved. Abbreviations: Sp. no., specimen number; -, missing data.

\begin{tabular}{|c|c|c|c|c|c|c|c|c|c|c|c|c|c|}
\hline \multirow[b]{2}{*}{ Sp. no. } & \multirow{2}{*}{$\begin{array}{c}\begin{array}{c}\text { T. adei } \\
\text { n. gen., } \\
\text { n. sp. }\end{array} \\
\text { TM } 112 \\
-00-99\end{array}$} & \multirow{2}{*}{ 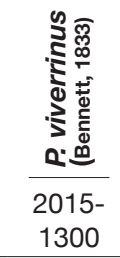 } & \multirow{2}{*}{ 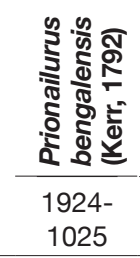 } & \multicolumn{2}{|c|}{$\begin{array}{l}\text { Puma concolor } \\
\text { (Linnaeus, 1771) }\end{array}$} & \multicolumn{2}{|c|}{$\begin{array}{c}\text { Lynx Iynx } \\
\text { (Linnaeus, 1758) } \\
\end{array}$} & \multicolumn{2}{|c|}{$\begin{array}{c}\text { Leopardus } \\
\text { pardalis } \\
\text { (Linnaeus, 1758) } \\
\end{array}$} & \multirow{2}{*}{ 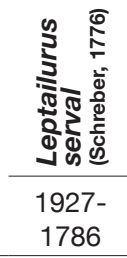 } & \multicolumn{3}{|c|}{$\begin{array}{c}\text { Neofelis nebulosa (Griffith } \\
1821 \text { ) }\end{array}$} \\
\hline & & & & $\begin{array}{r}2016- \\
1669\end{array}$ & $\begin{array}{l}1993- \\
4625\end{array}$ & $\begin{array}{l}1994- \\
2443\end{array}$ & $\begin{array}{c}1972- \\
84\end{array}$ & $\begin{array}{c}2005- \\
282\end{array}$ & $\begin{array}{c}2013- \\
33\end{array}$ & & $\begin{array}{c}1980- \\
16\end{array}$ & $\begin{array}{c}1971- \\
86\end{array}$ & $\begin{array}{c}1992- \\
3\end{array}$ \\
\hline Mc II & 93.13 & 89.72 & 89.35 & 89.21 & 91.20 & 89.06 & 84.74 & 86.67 & 85.51 & 87.59 & 81.08 & 84.84 & 85.06 \\
\hline Mc III & 100.00 & 100.00 & 100.00 & 100.00 & 100.00 & 100.00 & 100.00 & 100.00 & 100.00 & 100.00 & 100.00 & 100.00 & 100.00 \\
\hline Mc IV & 92.99 & 90.73 & 92.13 & 93.42 & 94.40 & 92.97 & 95.58 & 93.10 & 91.92 & 95.19 & 97.97 & 99.58 & 98.16 \\
\hline \multirow[t]{2}{*}{ Mc V } & 75.37 & 71.93 & 74.07 & 76.32 & 79.20 & 74.69 & 78.71 & 75.86 & 74.11 & 80.93 & 74.77 & 78.11 & 78.39 \\
\hline & $\begin{array}{c}\text { T. adei } \\
\text { n. gen., } \\
\text { n. sp. } \\
\end{array}$ & \multicolumn{2}{|c|}{$\begin{array}{l}\text { Prionailurus } \\
\text { viverrinus }\end{array}$} & \multicolumn{2}{|c|}{ Puma concolor } & \multicolumn{2}{|c|}{ Lynx Iynx } & \multicolumn{2}{|c|}{$\begin{array}{l}\text { Leopardus } \\
\text { pardalis }\end{array}$} & 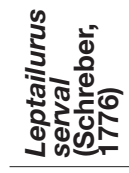 & \multicolumn{3}{|c|}{ Neofelis nebulosa } \\
\hline Sp. no. & $\begin{array}{l}\text { TM112 } \\
-00-99 \\
\end{array}$ & $\begin{array}{c}2015- \\
1300\end{array}$ & $\begin{array}{l}1884- \\
1170\end{array}$ & $\begin{array}{r}2016- \\
1669\end{array}$ & $\begin{array}{l}1993- \\
4625\end{array}$ & $\begin{array}{l}1994- \\
2443\end{array}$ & $\begin{array}{c}1972- \\
84\end{array}$ & $\begin{array}{c}2005- \\
282\end{array}$ & $\begin{array}{c}2013- \\
33\end{array}$ & $\begin{array}{l}1927- \\
1786\end{array}$ & $\begin{array}{c}1980- \\
16\end{array}$ & $\begin{array}{c}1971- \\
86\end{array}$ & $\begin{array}{c}1992- \\
3\end{array}$ \\
\hline Mt II & 92.31 & 92.27 & 90.54 & 88.50 & 88.79 & 91.23 & 91.31 & 90.07 & 91.67 & 92.62 & 89.26 & 89.52 & 89.32 \\
\hline Mt III & 100.00 & 100.00 & 100.00 & 100.00 & 100.00 & 100.00 & 100.00 & 100.00 & 100.00 & 100.00 & 100.00 & 100.00 & 100.00 \\
\hline Mt IV & 100.96 & - & 100.00 & - & 97.82 & 100.00 & 99.70 & 101.47 & 101.85 & 101.34 & 104.63 & 103.02 & 102.20 \\
\hline Mt V & 84.50 & 87.59 & 87.18 & 78.06 & 81.00 & 82.46 & 87.36 & 87.13 & 87.22 & 89.66 & 84.79 & 84.01 & 84.75 \\
\hline
\end{tabular}

\section{DESCRIPTION}

The tooth is almost complete except the top of the crown and is a little weathered, the enamel being flaked off in some parts (Fig. 5B). The crown, without any striation or crenulation, and the root, are compressed. The former displays an almost flat lingual surface and a slightly convex buccal one, with two, mesial and distal, cutting keels, the distal one being more trenchant, but both without any crenulation and striation. The proportions of (TM 74-0106) fit clearly the morphology of Dinofelis (mesiodistal and buccolingual maximum diameters are about $21.5 \mathrm{~mm}$ and $10.5 \mathrm{~mm}$ respectively, and the root height is $47 \mathrm{~mm}$ ). The size is close to that of some specimens studied by Werde- lin \& Lewis (2001: table 1), but the material from Toros Menalla remains undiagnostic at species level.

\section{DISCUSSION}

The type species, Dinofelis cristata, comes from the late Miocene of China and India but the genus has been recovered in other places in Asia, in Europe until south of Spain, and it is probably the most common fossil felid in Africa. In the latter continent, the earliest records of the genus are known from Lothagam, Kenya, into layers dated from 7.5 to $4 \mathrm{Ma}$ (Werdelin \& Lewis 2001; Werdelin \& Peigné 2010). The genus was represented in Chad in the lower Pliocene of Kossom Bougoudi (Bonis et al. 2008) by a piece of mandible and a piece of postcranium. 


\section{CONCLUSION}

Tchadailurus adei n. gen., n. sp. displays some characters indicating machairodont affinities. The typical machairodonts have large, trenchant, sometimes dirk-like or scimitar-like upper canines with several others features linked to these canines, particularly large opening of the mouth, elongated glenoid process, reduced ascending ramus of the mandible, low mandibular condyle, large mastoid process, reduced lower canine and presence of a mandibular flange. Tchadailurus adei $\mathrm{n}$. gen., n. sp. does not display all of these characters but is different from the extant and fossil Felinae in its quite compressed, relatively elongated and double keeled upper canines, which are a trade mark of the group although it is quite primitive when compared to other machairodonts, particularly those classified as Eumachairodontia (Christiansen 2013). Tchadailurus adei n. gen., n. sp. displays also postcranial characters that bring it near the machairodont felids. The long coracoid process of the scapula and its small facet for the $m$. biceps brachii, the elongated medial process of the scapholunar, the short and robust Mc I, and its associated first phalanx are closer to the morphology of early machairodontines such as Promegantereon ogygia and Pseudaelurus quadridentatus than to that of pantherines (Salesa et al. 2010b). Some Eumachairodontia, Amphimachairodus Kretzoi, 1929 and Lokotunjailurus, are known in the same geological level and, for some specimens, in the same localities as Tchadailurus $\mathrm{n}$. gen. despite the large difference in evolutionary degree. If the machairodonts form a monophyletic group, the divergence of the primitive Tchadailurus adei n. gen., n. sp. could be quite old and its lineage did exist together with those of more specialized lineages without leaving any known traces in the fossil record during a long time in Africa and elsewhere.

The new studied materials allow completing the list of the Toros Menalla carnivorans with addition of two taxa. This Chadian assemblage now includes 8 species of felids from the size of a wild cat to that of a lion. Such a great richness of the fossil felid assemblage is extremely rare in the fossil record. In Eurasia, the richest fossiliferous localities comprise not more than four or five species of felids with, for example, the late Miocene sites of Batallones and Las Casiones (Spain; Salesa et al. 2012a, b). In North America, no Miocene or Pliocene sites includes as many as felid species, and only the Pleistocene sites of Rancho La Brea counts up to eight felid species (Stock \& Harris 1992).

Obviously, this is in the particular context of the evolutionary history of the Felidae in Africa that Toros Menalla appears of paramount significance. The fossil record of the Felidae in Africa is heterogeneous, in both time and space (Werdelin \& Peigné 2010). The first half of the Neogene is very poorly documented, since only three genera of felids are known so far: the oldest record is Asilifelis Werdelin, 2011 from Kenya and dated to $c$. 18-20 Ma; it is followed by Diamantofelis Morales, Pickford, Soria \& Fraile, 1998 and Namafelis Morales, Pickford, Fraile, Salesa \& Soria, 2003, both from Namibia and dated to c. 17-17.5 Ma. During the second half of the Neogene appeared the sabre-toothed cats in the early late Miocene, with the genus Machairodus Kaup, 1833, first recorded in Bled Douarah, Tuni- sia, dated to $c$. 11-10 Ma (Kurtén 1976). The family reached its greatest diversity during the late Miocene-early Pliocene, and especially during the middle Pliocene (Werdelin \& Lewis 2005), with Toros Menalla being one of the richest felid assemblages. Given that $90 \%$ of the fossil occurrences are situated in eastern and southern Africa (Werdelin \& Peigné 2010), the great diversity at Toros Menalla appears as quite exceptional. The few other very rich and comparable African felid assemblages are more recent than Toros Menalla, of Pliocene or Pleistocene in age, and they include six or seven species (Awash 7, Omo Usno, Woranso-Mille, and probably Langebaanweg; Werdelin \& Peigné 2010); only the Laetolil Beds Upper Unit comprises as many taxa as Toros Menalla (Werdelin \& Peigné 2010; Werdelin et al. 2014).

The large number of carnivoran taxa, especially felids, in the fauna of Toros Menalla indicates certainly a favourable environment for this group of meat eater predators. Each of them was probably specialized in a type of prey depending on the size and habitat of these preys. We may imagine a diversified paleoenvironment with large plains occupied by big games which were elected prey for large felids or for the hunting hyaena Chasmaporthetes Hay, 1921 of which the long limb bones indicate a good runner (Galiano \& Frailey 1977). It is interesting to note that most of the Toros Menalla felids are machairodontines with different degrees of adaptation to that special way of life. Amphimachairodus kabir Peigné, Bonis, Likius, Mackaye, Vignaud \& Brunet, 2005, with its robust limbs (Peigné et al. 2005a) was probably hunting by ambush in a forested area favoured by the presence of water. Lokotunjailurus fanonei Bonis, Peigné, Likius, Mackaye, Vignaud, Brunet, 2010 was smaller than Amphimachairodus and reached the size of a leopard. Based on the paleobiology of its close relative Lokotunjailurus emageritus Werdelin, 2003, we infer that its relatively slender limbs "lacking extreme machairodont features" (except maybe by the robust first digit of the hand) certainly implies another way of preying upon medium-sized preys, as cf. Megantereon sp. and Dinofelis sp. probably did. The smallest species of the quintet, Tchadailurus adei $\mathrm{n}$. gen., n. sp., would have hunt smaller animals. This great spectrum of carnivores, especially the large ones, indicates scenery with diverse habitats stocked by diverse herbivorous animals and leaving in mind the idea of a "paradise lost".

\section{Acknowledgements}

This research was developed under the auspices of the following institutions: Chadian Ministère de l'Enseignement supérieur et de la Recherche; Centre national de Recherche pour le Développement, N'Djamena; University of N'Djamena; French Ministère de l'Enseignement supérieur et de la Recherche; Centre national de la Recherche scientifique, University of Poitiers (UFR SFA); French Ministère des Affaires étrangères (French Embassy in Chad). We thank very much Christine Argot and Geraldine Veron for access to the collections of the MNHN, Manuel J. Salesa for sharing data on Promegantereon ogygia, Ghislaine Florent, Guylaine Reynaud and Mélanie Pourade (administrative guidance), Jérôme Surault (support 
in N'Djamena), Xavier Valenin who prepared the fossils and all contributors to the MPFT field missions. The photographs are from one of us (L. de B.) except in Figure 1D (R. Boitel) and prepared by Sabine Riffaut who prepared also the figures. We are indebted to the reviewers D. Geraads and M. Salesa whose criticisms and remarks greatly improved the manuscript.

\section{REFERENCES}

Abel O. 1922. - Lebensbilder aus der Tierwelt der Vorzeit. Gustav Fischer, Iena, 630 p. https://doi.org/10.5962/bhl.title.61701

BEAUMONT G. DE 1975. — Recherches sur les Félidés (Mammiferes, Carnivores) du Pliocène inférieur des sables à Dinotherium des environs d'Eppelsheim (Rheinhessen). Archives des Sciences, Genève 28: 369-405.

BEAUMONT G. DE 1978. - Notes complémentaires sur quelques Félidés (Carnivores). Archives des Sciences, Genève 31: 219-227.

Bonis L. De, Peigné S., Likius A., Mackaye H. T., Vignaud P. \& BRUNET M. 2005. - Hyaenictitherium minimum, a new ictithere (Mammalia, Carnivora, Hyaenidae) from the Late Miocene of Toros-Menalla, Chad. Comptes Rendus Palevol 4: 671-679. https:// doi.org/10.1016/j.crpv.2005.09.020

Bonis L. De, Peigné S., Likius A., Mackaye H. T., Vignaud P. \& BRUnet M. 2007a. - The oldest African fox (Vulpes riffautae n. sp., Canidae, Carnivora) recovered in Late Miocene deposits of the Djurab desert. Chad. Naturwissenschaften 94: 575-580. https://doi.org/10.1007/s00114-007-0230-6

Bonis L. De, Peigné S., Likius A., Mackaye H. T., Vignaud P. \& BRUNET M. 2007b. - First occurrence of the 'hunting hyena' Chasmaporthetes in the Late Miocene fossil bearing localities of Toros Menalla Chad (Africa). Bulletin de la Société géologique de France 178: 317-326. https://doi.org/10.2113/gssgfbull.178.4.317

Bonis L. De, Peigné S., Mackaye H. T., Likius A., Vignaud P. \& BRUneT M. 2008. - The fossil vertebrate locality Kossom Bougoudi, Djurab desert, Chad: A window in the distribution of the carnivoran faunas at the Mio-Pliocene boundary in Africa. Comptes Rendus Palevol 7: 571-581. https://doi.org/10.1016/j. crpv.2008.10.004

Bonis L. De, Peigné S., Guy F., Likius A., Mackaye H. T., VigNAUD P. \& BRUNET M. 2009. - A new mellivorine (Carnivora, Mustelidae) from the late Miocene of Toros Menalla, Chad. Neues Jahrbuch für Geologie und Paläontologie Abhandlungen 252: 33-54. https://doi.org/10.1127/0077-7749/2009/0252-0033

Bonis L. De, Peigné S., Guy F., Likius A., Mackaye H. T., Vignaud P. \& BRUneT M. 2010a. - Hyaenidae (Carnivora) from the late Miocene of Toros-Menalla, Chad. Journal of A frican Earth Sciences 58: 561-679. https://doi.org/10.1016/j.jafrearsci.2010.06.003

Bonis L. de, Peigné S., Likius A., Mackaye H. T., Vignaud P. \& BRUNET M. 2010b. - New sabre-toothed cats in the late Miocene of Toros Menalla (Chad). Comptes Rendus Palevol 9: 221-227. https://doi.org/10.1016/j.crpv.2010.07.018

ChristiansEN P. 2006. - Sabertooth characters in the clouded leopard (Neofelis nebulosa Griffiths 1821). Journal of Morphology 267: 1186-1198. https://doi.org/10.1002/jmor.10468

Christiansen P. 2013. - Phylogeny of the sabertoothed felids (Carnivora: Felidae: Machairodontinae). Cladistics 29: 543-559. https://doi.org/10.1111/cla.12008

Croizet J. B. \& Jobert A. C. G. 1828. - Recherches sur les ossemens fossiles du département du Puy-de-Dôme. Paris, $224 \mathrm{p}$.

Evans H. E. 1993. - Miller's Anatomy of the Dog. W.B. Saunders Company, Philadelphia, 872 p.

GalianO H. \& Frailey D. 1977. - Chasmaporthetes kani, new species from China, with remarks on phylogenetic relationships of genera within the Hyaenidae (Mammalia, Carnivora). American Museum Novitates 2632: 1-16. http://hdl.handle.net/2246/2028
Geraads D., Alemseghed Z. \& Bellon H. 2002. - The late Miocene mammalian fauna of Chorora, Awash basin, Ethiopia: systematics, biochronology and 40K-40Ar ages of the associated volcanics. Tertiary Research 21: 113-122.

GeraAds D. \& PeIgné S. 2017. - Re-appraisal of 'Felis' pamiri Ozansoy, 1959 (Carnivora, Felidae) from the Upper Miocene of Turkey: the earliest pantherin cat? Journal of Mammalian Evolution 24: 415-425. https://doi.org/10.1007/s10914-016-9349-6

Haile Selassie Y., Woldegabriel G., White T. D., Bernor R. L., Degusta D., Renne P. R., Hart W. K., Vrba E., StanLEY A. \& Howell F. C. 2004. - Mio-Pliocene mammals from the Middle Awash, Ethiopia. Geobios 37: 536-552. https://doi. org/10.1016/j.geobios.2003.03.012

Hendey Q. B. 1974. - The late Cenozoic Carnivora of the SouthWestern Cape Province. Annals of the South African Museum 63: 1-369. https://www.biodiversitylibrary.org/page/40935484

HENDEY Q. B. 1978. — Late Tertiary Hyaenidae from Langebaanweg, South Africa, and their relevance to the phylogeny of the family. Annals of the South African Museum 76: 265-297.

HeNDEY Q. B. 1980. - Agriotherium (Mammalia, Ursidae) from Langebaanweg, South Africa, and relationships of the genus. Annals of the South African Museum 81: 1-109. https://www. biodiversitylibrary.org/page/40751715

Howell F. C. 1987. - Preliminary observations on Carnivora from the Sahabi Formation, Libya, in Boaz N. T., El-Arnauti A., Gaziry A. W., Heinzelin J. DE \& Boaz D. D. (eds), Neogene Paleontology and Geology of Sahabi. Alan R. Liss, New York: 153-181.

Howell F. C. \& GARCía N. 2007. — Carnivora (Mammalia) from Lemudong'o (Late Miocene: Narok District, Kenya). Kirtlandia 56: 121-139. https://www.biodiversitylibrary.org/page/51811226

Johnson W. E., Eizirik E., Pecon-Slattery J., Murphy W. J., Antunes A., Teeling E. \& O'Brien S. J. 2006. — The Late Miocene radiation of modern Felidae: a genetic assessment. Science 311: 73-77. https://doi.org/10.1126/science.1122277

KiTTL E. 1887. — Beiträge zur Kenntnis der fossilen Säugethiere von Maragha in Persien. 1. Carnivora. Annalen des K.K. naturhistorischen Hofmuseums 2: 317-338. https://biodiversitylibrary. org/page/5661675

KRETZOI M. 1929. - Materialien zur phylogenetischen Klassifikation der Aeluroïdeen, in 10 th International Congress of Zoology, Budapest 1927: 1293-1355.

KreTZOI M. 1938. — Die Raubtiere von Gombaszög nebst einer Übersicht der Gesamtfauna. Annales Musei Nationalis Hungarici 31: 88-157.

Kretzor M. 1951. - The Hipparion-Fauna from Csákvár. Földtani Közlöny 81: 402-417. https://biodiversitylibrary.org/ page/50760534

KURTÉN B. 1976. - Fossil Carnivora from the Late Tertiary of Bled Douarah and Cherichira (Tunisia). Notes du Service géologique de Tunisie 42: 77-214.

KURTÉN B. 1978. - The lynx from Etouaires, Lynx issiodorensis (Croizet \& Jobert), late Pliocene. Annales Zoologici Fennici 15: 314-322. http://www.jstor.org/stable/23733663

Lebatard A. E., Bourlès D. L., Duringer P., Jolivet M., Braucher R., Carcaillet J., Schuster M., Arnaud N., Monie P., Lihoreau F., Likius A., Mackaye H. T., Vignaud P. \& BRUNET M. 2008. - Cosmogenic nuclide dating of Sahelanthropus tchadensis and Australopithecus bahrelghazali: Mio-Pliocene hominids from Chad. Proceedings of the National Academy of Sciences of the United States of America 105: 3226-3231. https:// doi.org/10.1073/pnas.0708015105

Lebatard A. E., Bourles D., BraUCHER R., ARNOld M., Duringer P., Jolivet M., Moussa A., Deschamps P., Roquin C., CarCaillet J., Schuster M., Arnaud N., Monie P., Lihoreau F., Likius A., Mackaye H.T., Vignaud P. \& Brunet M. 2010. - Application of the authigenic $10 \mathrm{Be} / 9 \mathrm{Be}$ dating method to continental sediments: reconstruction of the Mio-Pleistocene sedimentary 
sequence in the early hominid fossiliferous areas of the northern Chad Basin. Earth and Planetary Science Letters 297: 57-70. https:// doi.org/10.1016/j.epsl.2010.06.003

LEGENDRE S. 1986. - Analysis of mammalian communities from the late Eocene and Oligocene of southern France. Palaeovertebrata 16: 191-212.

LYDEKKER R. 1877. - Notices on new and other Vertebrata from Indian tertiary and secondary rocks. Records of the Geological Survey of India 10 (1): 30-43, 76-83.

LYDEKKER R. 1884. - Indian Tertiary and Post-Tertiary Vertebrata. Vol. 2. Part. 6. Siwalik and Narbada Carnivora. Memoirs of the Geological Survey of India, Palaeontologia Indica 10: 178-351. https://doi.org/10.1080/00222938409459810

MacDonald D. W. 2001. - The Encyclopedia of Mammals. Oxford University Press, Oxford, $976 \mathrm{p}$.

Morales J., Pickford M. \& Soria D. 2005. - Carnivores from the late Miocene and basal Pliocene of the Tugen Hills, Kenya. Revista de la Sociedad Geológica de Espańa 48: 39-61.

Olive F. 2006. - Évolution des grands Carnivores au Plio-Pléistocène en Afrique et en Europe occidentale. L'Anthropologie 110: 850-869. https://doi.org/10.1016/j.anthro.2006.10.005

Peigné S. \& Heizmann E. P. J. 2003. - The Amphicyonidae (Mammalia, Carnivora) from Ulm-Westtangente (MN 2, Early Miocene), Baden-Württemberg, Germany - Systematics and ecomorphology. Stuttgarter Beiträge zur Naturkunde Serie B (Geologie und Paläontologie 343: 1-133.

Peigné S., Bonis L. De, Likius A., Mackaye H. T., Vignaud P. \& BRUNET M. 2005a. - New machairodontine (Carnivora, Felidae) from the Late Miocene hominid of Toros-Menalla Chad. Comptes Rendus Palevol 4: 243-253. https://doi.org/10.1016/j. crpv.2004.10.002

Peigné S., Bonis L. de, Likius A., Mackaye H. T., Vignaud P. \& BRUNET M. 2005b. - The oldest modern mongoose (Carnivora, Herpestidae) from Africa: Galerella sanguinea from the late Miocene hominid-bearing locality TM 266, Toros-Menalla, Chad. Naturwissenschaften 92: 287-292. https://doi.org/10.1007/ s00114-005-0626-0

Peigné S., Bonis L. De, Likius A., Mackaye H. T., Vignaud P. \& BRUNET M. 2008a. - Late Miocene Carnivora from Chad: Lutrinae, Mustelidae. Zoological Journal of the Linnean Society 152 793-846. https://doi.org/10.1111/j.1096-3642.2008.00377.x

Peigné S., Bonis L. De, Likius A., Mackaye H. T., Vignaud P. \& BRUneT M. 2008b. - Late Miocene Carnivora from Chad: Herpestidae, Viverridae and small-sized Felidae. Comptes Rendus Palevol 7: 499-528. https://doi.org/10.1016/j.crpv.2008.10.002

PILGRIM G. E. 1915. - Note on the new feline genera Sivaelurus and Paramachaerodus and on the possible survival of the subphylum in modern times. Records of the Geological Survey of India 45: 138-155.

Pilgrim G. E. 1931. - Catalogue of the Pontian Carnivora of Europe. Department of Geology-British Museum London, $174 \mathrm{p}$.

Salesa M. J., ANTÓN M., Turner A. \& Morales J. 2005. - Aspects of the functional morphology in the cranial and cervical skeleton of the sabre-toothed cat Paramachairodus ogygia (Kaup, 1832) (Felidae, Machairodontinae) from the Late Miocene of Spain implications for the origins of the machairodont killing bite. Zoological Journal of the Linnean Society 144: 363-377. https:// doi.org/10.1111/j.1096-3642.2005.00174.x

Salesa M. J., Antón M., Turner A., Alcala L., Montoya P. \& MoralES J. 2010a. - Systematic revision of the late Miocene sabre-toothed felid Paramachaerodus in Spain. Palaeontology 53: 1369-1391. https://doi.org/10.1111/j.1475-4983.2010.01013.x

Salesa M. J., Antón M., Turner A. \& Morales J. 2010b. — Functional anatomy of the forelimb in Promegantereon ogygia (Felidae, Machairodontinae, Smilodontini) from the Late Miocene of Spain and the origins of the sabre-toothed felid model. Journal of Anatomy 216: 381-396. https://doi.org/10.1111/j.1469-7580.2009.01178.x

Salesa M. J., Antón M., Morales J. \& Peigné S. 2012a. - Systematics and phylogeny of the small felines (Carnivora, Felidae) from the Late Miocene of Europe: a new species of Felinae from the Vallesian of Batallones (MN 10, Madrid, Spain). Journal of Systematic Palaeontology 10: 87-102. https://doi.org/10.1080/14 772019.2011 .566584

Salesa M. J., Pesquero M. D., Siliceo G., Antón M., Alcalá L. \& MORALES J. 2012b. - A rich community of Felidae (Mammalia, Carnivora) from the late Miocene (Turolian, MN 13) site of Las Casiones (Villalba Baja, Teruel, Spain). Journal of Vertebrate Paleontology 32: 658-676. https://doi.org/10.1080/02724634.2 012.649816

Salesa M. J., Montoya P., Alcalá L. \& Morales J. 2003. — El genero Paramachairodus Pilgrim, 1913 (Felidae, Machairodontinae) en el Mioceno superior espańol. Coloquios de Paleontología Vol. Ext. 1: 603-615.

SMITH J. B. \& DODSON P. 2003. - A proposal for a standard terminology of anatomical notation and orientation in fossil vertebrate dentitions. Journal of Vertebrate Paleontology 23: 1-12. https://doi. org/10.1671/0272-4634(2003)23[1:APFAST]2.0.CO;2

SPASSOV N. \& GERAADS D. 2015. - A new felid from the Late Miocene of the Balkans and the content of the genus Metailurus Zdansky, 1927 (Carnivora, Felidae). Journal of Mammalian Evolution 22: 45-56. https://doi.org/10.1007/s10914-014-9266-5

STOCK C. \& HARrIS J. M. 1992. - Rancho La Brea: a record of Pleistocene life in California. Natural History Museum of Los Angeles, Science Series 37: 1-113. https://hdl.handle.net/2027/ uc1.31158001757441

Teilhard de Chardin P. \& Leroy P. 1945. — Les Félidés de Chine. Publications de l'Institut de Géobiologie, Pékin 11: 18-23.

Vignaud P., Duringer P., Mackaye H. T., Likius A., Blondel C., Boisserie J.-R., Bonis L. DE, EisenMann V., ETIENNE M. E., GeraAdS D., Guy F., LeHMANn T., LiHOREAu F., Lopez-Martinez N., Mourer-Chauviré C., Otero O., Rage J.-C., Schuster M., Viriot L., Zazzo A. \& Brunet M. 2002. - Geology and Palaeontology of the Upper Miocene Toros Menalla hominid locality, Chad. Nature 418: 152-155. https://doi.org/10.1038/nature00880

Weithofer K. A. 1888. - Beiträge zur Kenntnis der Fauna von Pikermi bei Athen. Beiträge zur Paläontologie Österreich Ungarns und des Orients, Wien 6: 225-292.

Werdelin L. 2003. - Mio-Pliocene Carnivora from Lothagam, Kenya, in LeaKey M. G. \& HARRIS J. M (eds), Lothagam. The Dawn of Humanity in Eastern Africa. Columbia University Press, New York: 261-330.

WERDELIN L. \& LEWIS M. E. 2001. — Revision of the genus Dinofelis (Mammalia, Felidae). Zoological Journal of the Linnean Society 132: 147-258. https://doi.org/10.1111/j.1096-3642.2001.tb02465.x

Werdelin L. \& LeWIS M. E. 2005. - Plio-Pleistocene Carnivora of eastern Africa: species richness and turnover patterns. Zoological Journal of the Linnean Society 144: 121-144. https://doi. org/10.1111/j.1096-3642.2005.00165.x

Werdelin L. \& Peigné S. 2010. - Carnivora, in Werdelin L. \& SANDERS W. J. (eds), Cenozoic Mammals of Africa. University of California Press, Berkeley: 603-657.

WERDELIn L., Turner A. \& SOlOUNIAS N. 1994. — Studies of fossil hyaenids: the genera Hyaenictis Gaudry and Chasmaporthetes Hay, with a reconsideration of the Hyaenidae of Langebaanweg, South Africa. Zoological Journal of the Linnean Society 111: 197-217. https://doi.org/10.1111/j.1096-3642.1994.tb01483.x

Werdelin L., Lewis M. E. \& Haile-Selassie Y. 2014. — MidPliocene Carnivora from the Woranso-Mille area, Afar Region, Ethiopia. Journal of Mammal Evolution 21: 331-347. https://doi. org/10.1007/s10914-013-9250-5

ZDANSKY O. 1924. - Jungtertiäre Carnivoren Chinas. Palaeontologia Sinica Series C 2: 1-149.

Submitted on 18 May 2017; accepted on 2 October 2017; published on 15 February 2018. 